OPEN ACCESS

Edited by:

Kieran Jordan,

Teagasc - The Irish Agriculture and Food Development Authority,

Ireland

Reviewed by:

Zhao Chen,

Clemson University, USA

Mareike Wenning,

Technische Universität München,

Germany

*Correspondence:

Solimar G. Machado

solimar.machado@ifnmg.edu.br

tPresent address:

Sophie Marchand,

Metabolic and Cardiovascular Diseases, University Hospital Ghent,

Ghent, Belgium

Specialty section:

This article was submitted to

Food Microbiology,

a section of the journal

Frontiers in Microbiology

Received: 30 August 2016

Accepted: 14 February 2017

Published: 01 March 2017

Citation:

Machado SG, Baglinière $F$,

Marchand S, Van Coillie E,

Vanetti MCD, De Block J and Heyndrickx M (2017) The Biodiversity

of the Microbiota Producing Heat-Resistant Enzymes Responsible for Spoilage in Processed Bovine Milk and Dairy Products.

Front. Microbiol. 8:302. doi: 10.3389/fmicb.2017.00302

\section{The Biodiversity of the Microbiota Producing Heat-Resistant Enzymes Responsible for Spoilage in Processed Bovine Milk and Dairy Products}

\author{
Solimar G. Machado ${ }^{*}$, François Baglinière ${ }^{2}$, Sophie Marchand ${ }^{3 t}$, Els Van Coillie ${ }^{3}$, \\ Maria C. D. Vanetti2, Jan De Block ${ }^{3}$ and Marc Heyndrickx ${ }^{3,4}$
}

\begin{abstract}
${ }^{1}$ Instituto Federal do Norte de Minas Gerais - Campus Salinas, Salinas, Brazil, ${ }^{2}$ Department of Microbiology, Universidade Federal de Viçosa, Viçosa, Brazil, ${ }^{3}$ Technology and Food Science Unit, Flanders Research Institute for Agriculture, Fischeries and Food (ILVO), Melle, Belgium, ${ }^{4}$ Department of Pathology, Bacteriology and Poultry Diseases, Ghent University, Merelbeke, Belgium
\end{abstract}

Raw bovine milk is highly nutritious as well as pH-neutral, providing the ideal conditions for microbial growth. The microbiota of raw milk is diverse and originates from several sources of contamination including the external udder surface, milking equipment, air, water, feed, grass, feces, and soil. Many bacterial and fungal species can be found in raw milk. The autochthonous microbiota of raw milk immediately after milking generally comprises lactic acid bacteria such as Lactococcus, Lactobacillus, Streptococcus, and Leuconostoc species, which are technologically important for the dairy industry, although they do occasionally cause spoilage of dairy products. Differences in milking practices and storage conditions on each continent, country and region result in variable microbial population structures in raw milk. Raw milk is usually stored at cold temperatures, e.g., about $4^{\circ} \mathrm{C}$ before processing to reduce the growth of most bacteria. However, psychrotrophic bacteria can proliferate and contribute to spoilage of ultrahigh temperature $(\mathrm{UHT})$ treated and sterilized milk and other dairy products with a long shelf life due to their ability to produce extracellular heat resistant enzymes such as peptidases and lipases. Worldwide, species of Pseudomonas, with the ability to produce these spoilage enzymes, are the most common contaminants isolated from cold raw milk although other genera such as Serratia are also reported as important milk spoilers, while for others more research is needed on the heat resistance of the spoilage enzymes produced. The residual activity of extracellular enzymes after high heat treatment may lead to technological problems (off flavors, physico-chemical instability) during the shelf life of milk and dairy products. This review covers the contamination patterns of cold raw milk in several parts of the world, the growth potential of psychrotrophic bacteria, their ability to produce extracellular heat-resistant enzymes and the consequences for dairy products with a long shelf life. This problem is of increasing importance because of the large worldwide trade in fluid milk and milk powder.

Keywords: microbial dynamics, psychrotrophic, Pseudomonas, Serratia, peptidase, lipase, heat-resistant enzyme, spoilage 


\section{INTRODUCTION}

The dairy industry has a long tradition of safeguarding the safety and quality of consumer milk. Two main processes are at the basis of this quality system: cooling of the raw milk to temperatures below $7-10^{\circ} \mathrm{C}$ until processing and heating the milk in a dairy plant to produce different types of consumer milk depending on the heating process applied: pasteurized, extended shelf life (ESL), ultra-high temperature treated (UHT) or sterilized milk. The most consumed milk worldwide is either pasteurized or UHT. These heating processes eliminate pathogens and increase the shelf life of unopened packages. Pasteurized milk should be stored at refrigeration temperature $\left(4-7^{\circ} \mathrm{C}\right)$ for a shelf life of about 2 weeks. On the other hand, UHT milk can be stored for 6-12 months at ambient temperature. However, spoilage can still happen during the predicted shelf life. Spoilage can be considered as any change, which renders a food product unacceptable for human consumption or for business to business trading. Besides physical damage to milk packaging, it is manifested by growth of microorganisms or enzymatic reactions leading to souring, changes in texture, or development of offflavors.

The spoilage phenomena and mechanisms can be very different in the various types of consumer milk. The predicted and obtained shelf life of pasteurized milk is mainly determined by the presence and growth of aerobic psychrotrophic endospore formers of which members of the Bacillus cereus group are the most important spoilers, but other species of the genus Bacillus and allied genera are involved as well. Because the endospores resist the pasteurization process, the main spoilage mechanism is their subsequent germination and outgrowth with the production of spoilage enzymes in the pasteurized milk. Gopal et al. (2015) published a recent review for this type of spoilage. Nevertheless, it cannot be excluded that in some dairies postpasteurization by mainly pseudomonads is still a problem leading to spoiled packages by the production of spoilage enzymes during psychrotrophic growth under refrigeration. Moreover, spoilage enzymes are already produced in the cooled raw milk by psychrotrophs like endospore formers in the vegetative state and pseudomonads. The heat resistance under pasteurization or the role of these enzymes in spoilage is largely unknown and probably of less importance in this type of milk. Native milk proteases and lipases may also be important factors limiting the shelf life of pasteurized milk in particular conditions of low bacterial counts during refrigerated storage (Santos et al., 2003).

For UHT and sterilized milk processed with a low risk of post-heat treatment contamination, the unwanted presence and even outgrowth of micro-organisms is a rare event and restricted to a few particular endospore formers of which Bacillus sporothermodurans is the main cause of concern (Scheldeman et al., 2006). However, the most important spoilage problem of UHT and sterilized milk and related UHT dairy products (cream, custard, evaporated condensed milk, chocolate milk, flavored milk, infant formula, drinks based on milk) is caused by enzymes which resist UHT treatment and which are mainly of bacterial origin. These bacteria are psychrotolerants such as pseudomonads which are able to grow and to produce these thermotolerant enzymes in the cooled raw milk before heat processing. Also milk powder, which is made with a low, medium or high heat process, can contain these thermotolerant enzymes and as a consequence products made with these contaminated milk powders (e.g., desserts, ice mixes, chocolate, confectionery, reconstituted milk) can show a similar spoilage mechanism.

With the current world production and distribution systems of the food industry, there is a real need for high-quality products with ESL. The dairy industry must constantly optimize and improve the processes that result in products that meet business and consumers' demands and which can be exported over long distances and sometimes in unfavorable storage conditions without loss of quality. Despite the further development of the dairy industry in the last century, premature spoilage of milk continues to be a problem and causes considerable environmental and economic losses (Vanetti, 2009). These economic losses are caused by the direct costs of recalls of products and indirectly by the image damage to the companies concerned. A recall of consumer milk typically occurs upon complaints of gelation or sedimentation of milk or sensory deviations before the shelf life has expired. Such a recall depends on the size of the batch of processed raw milk. Recall costs involve the direct sales costs of the recalled goods but also administrative and logistical costs. It can be estimated that total costs are a multitude of the direct costs related to a recall. If the recall pertains to a product containing milk powder, the recall costs may be greater than for consumer milk.

A safe, abundant, and high-quality milk supply should be the goal of every dairy producer in the world. To achieve this, the control strategies must start at the farm and continue throughout processing. To meet increased raw milk quality standards, producers must adopt practices that reduce mastitis and bacterial contamination of raw milk. Raw bovine milk and dairy products are characterized by a wide microbial biodiversity, with more than 150 species identified (Delbès et al., 2007; Vithanage et al., 2014). Various microbial consortia of raw milk have been studied, particularly in relation to the geographical origin in order to maintain and exploit the microbial diversity in traditional dairy products (Boubendir et al., 2016). Furthermore, von Neubeck et al. (2015) estimated that about $18 \%$ of isolates from raw milk belong to hitherto unknown species, indicating that a large fraction of the milk microbiota is still unexplored. Nowadays, studies of the structure and the dynamics of milk microbiota based on a polyphasic taxonomic approach as well as culture-independent methods have advanced knowledge. In this review, the most recent findings on the biodiversity of the milk microbiota contributing to spoilage of milk and dairy products with a long shelf life at mostly ambient temperature will be discussed. The biodiversity will be dealt with on the taxonomic and enzymatic level, along with the specific technological problems caused by the heat-resistant or thermotolerant enzymes (peptidases, lipases, and phospholipases) and possible control strategies. 


\section{SOURCES OF CONTAMINATION OF RAW MILK}

Milk is supposed to be sterile in healthy udder cells. When it leaves the udder it normally contains low numbers of microorganisms, typically ranging from several hundred to a few thousand colony-forming units per milliliter (CFU/mL). De Jonghe et al. (2011) measured a total aerobic plate count around $10,000 \mathrm{cfu} / \mathrm{ml}$ at the beginning of storage of the raw milk. But in some countries, raw milk may occasionally be contaminated with much higher numbers of up to $10^{7} \mathrm{CFU} / \mathrm{mL}$ at the beginning of storage (Machado et al., 2015) depending on the hygienic conditions under which the milk is obtained.

The diversity of raw milk contamination is influenced by handling factors at the production farms. Numerous microorganisms, including bacteria, yeasts, and molds constitute the complex ecosystem present in milk and dairy products. At the farm level, microbial contamination of bulk tank milk occurs via three main sources: bacterial contamination from the external surface of the udder and teats, from mastitis organisms from within the udder and from the surface of the milking equipment (Murphy and Boor, 2000). Air, water, feed, grass, feces, and soil could also represent important sources of milk contamination. Vacheyrou et al. (2011) proved that most of the fungi and bacteria found in milk were also present in the barn and milking parlor environments.

The teat surface may be an important route of milk contamination (Vacheyrou et al., 2011) and a positive association has been found between udder hygiene score and bacterial counts in bulk tank milk (Elmoslemany et al., 2010). Verdier-Metz et al. (2012) have noted that the composition of the microbiota on teat skin varied qualitatively and quantitatively from one farm to another. This can be attributed to different factors including the farming practices as well as dairy breed, type of feed, type of barn, milking system and quality of milking hygiene practices (Monsallier et al., 2012). Mallet et al. (2012) have shown that teat care has more influence on the composition of technologically relevant microbial groups than on the composition of other groups such as Pseudomonas and other Gram-negative bacteria in milk.

Braem et al. (2012) showed that the contaminant microbiota of udder is influenced by the infection status of the udder quarters. The contaminant microbiota from non-infected quarters consists predominantly of Aerococcus, Acinetobacter, Corynebacterium, Jeotgalicoccus, Kocuria, Staphylococcus, and Bifidobacterium genera (Ryser, 1999; Jost, 2007; Braem et al., 2012). Besides the diversity of bacterial genera found on the teat apex of dairy cows, Braem et al. (2012) highlighted the presence of a variety of different species of Corynebacterium and Staphylococcus. The udder of dairy cows may be a source of commensal skin associated bacteria, opportunistic pathogenic bacteria, and mastitis-causing pathogens, which could be found in raw milk.

There are some conflicting results on the importance of udder hygiene in the contamination of milk, depending on the type of microorganism. Masiello et al. (2014) showed that the percentage of dirty udders in the milking parlor combined with the herd size is significantly associated to the raw milk quality (related to psychrotrophic spore formers) and the shelf life of pasteurized milk. On the other hand, Richard et al. (1981) observed that intensive washing of milking equipment and udder preparation (individual washings) results in raw milk that contains a majority of spoilage microorganisms, such as coliforms and Pseudomonas spp. In contrast, minimal hygiene around the udder yields raw milk with a majority of useful cheesemaking microorganisms including salt-tolerant microbiota such as Micrococcus, Arthrobacter, Microbacterium, Brevibacterium, and Staphylococcus spp. (Lafarge et al., 2004) and the lactic acid bacteria (LAB) (Desmasures et al., 1997b).

Regarding milking hygiene practices, the cleanliness of milking equipment and storage tanks could affect the introduction and increase in the number of pathogens and other milk quality-affecting bacteria. The contaminant microbiota may persist in water, teat cups, and milking equipment over time indicating a continuous source of microorganisms (Flach et al., 2014; Nucera et al., 2016). This persistence can possibly be explained by biofilm formation and consequent high resistance to disinfection. The milking machine type influences the level of microorganisms in milk, suggesting that these machines are microbiological reservoirs (Mallet et al., 2012). It is well established that the milking machine and storage equipment are commonly colonized by bacterial biofilms (Boari et al., 2009; Marchand et al., 2012; Teh et al., 2012, 2014a). In fact, strains belonging to Pseudomonas fluorescens, Staphylococcus aureus, Bacillus licheniformis, Serratia liquefaciens, Hafnia alvei, and Streptococcus uberis isolated from raw milk tankers are capable of producing biofilms on stainless steel (Teh et al., 2011). In addition to the specific ability of each species or strain, the bacterial adhesion may be affected by the surface roughness and the effectiveness of cleaning processes (Cais-Sokolinska and Pikul, 2008; Vilar et al., 2012). Although biofilm formation within a tanker is of concern, the risk of biofilm development seems to be greater in other areas of a dairy plant (Darchuk et al., 2015).

The quality of water used for cleaning process could affect the contamination level on the surfaces and equipment. A farm water purification system is advised (Garcia Barbero, 1998). In a study performed by Vilar et al. (2008), the bulk-tank bacterial count increased by $12 \%$ when non-chlorinated water was used for cleaning. Drinking water and cow feed (including grass silage, soy bean meal, and pasture) are other possible routes for raw milk contamination with Pseudomonas spp. through fecal excretion and subsequent contamination of the udder (Marchand et al., 2009a).

Microbial contamination could be transferred from the barn environment, including settled dust and hay, to raw milk. Despite the massive microbiota in the barn, less than a third of this bacterial diversity may be found in milk samples, indicating that there is a partial barrier between barn and milk (Vacheyrou et al., 2011). Differences in housing strategy and feed formulation may contribute to the composition of the bacterial population of milk. Coorevits et al. (2010) demonstrated a greater number of thermotolerant spore-forming bacteria in milk from conventional dairy farms than from organic dairy farms. In the 
latter, a higher occurrence of Bacillus cereus was attributed to differences in housing strategy. It remains to be investigated whether operational management could also influence other spoilage bacteria.

The wide variety of sources of contamination contribute to the complexity of raw milk microbiota; further investigation is clearly needed to fully understand the routes of raw milk contamination with particular spoilage bacteria like pseudomonads and subsequent control of these microbial sources.

\section{COMPOSITION OF RAW MILK MICROBIOTA AND THE IMPACT OF COLD STORAGE}

To understand how the specific spoilage microbiota evolves in raw milk, it is important to know the dynamics of its total microbial composition as a function of the cooled storage time. As raw milk is contaminated during the milking process, several studies have been performed with the aim of identifying the predominant microbiota present in raw cow's milk immediately after milking (Table 1). Although the region where milk samples were collected and the methods used for isolation and identification could influence the results obtained for the predominant microbiota in fresh raw milk, the genus Lactobacillus was identified within the dominant microbiota in French raw milk using agar-based methods (Vacheyrou et al., 2011) and 16S rRNA gene-based analyses (Delbès et al., 2007). Lactobacillus delbrueckii spp. lactis and Lactobacillus casei as well as Lactococcus lactis, also found in Italian milk samples, have a particular importance within the dairy industry (Bertazzoni Minelli et al., 2004; Quigley et al., 2013). Propionibacterium freudenreichii and Corynebacterium have been detected in raw milk in a recent study (Quigley et al., 2013). Therefore, the technologically relevant Gram-positive bacteria represent the most prevalent bacterial populations in fresh raw milk obtained from healthy cows and under hygienic conditions. However, according to studies described in Table 1, some species from the genera Staphylococcus and Streptococcus are often detected in fresh raw milk as well as members of the Clostridiales. While Staphylococcus and Streptococcus have been associated with mastitis infections (Todhunter et al., 1995; Zadoks et al., 2001), Clostridium lituseburense and Clostridium glycolicum, predominant in cow manure and dairy wastewater, are associated with environmental contamination (Liu et al., 2009; St-Pierre and Wright, 2013, 2014).

Cold storage of raw milk is normally applied to reduce the growth of most bacteria. In general, milk is not directly processed after milking and it is stored up to 4 days depending on the legislation of the country (Perin et al., 2012). In dairy processing plants, additional storage until processing is possible (von Neubeck et al., 2015). In an effort to reduce the total aerobic plate count of raw milk, a lower storage temperature ( 1 to $4^{\circ} \mathrm{C}$ ) is applied, leading to the perception that raw milk could be stored for a longer period before further processing (De Jonghe et al., 2011). Cold storage creates selective conditions for growth of psychrotrophs and considerable changes in the bacterial communities will occur.

The microbiota of fresh raw milk has been described as predominately Gram-positive, but after cold storage, Gram-negative species become predominant in most studies (Table 2). The differences in the predominant microbiota after refrigeration can be explained by the variety of cold storage conditions and the original raw milk microbiota in each study. The dominant Gram-negative microbiota found in raw milk stored at cold temperatures belong to the genera Pseudomonas, Stenotrophomonas, Aeromonas, Hafnia, Acinetobacter, Serratia, and Chryseobacterium and Gram-positives include Bacillus, Paenibacillus, Lactococcus, Enterococcus, Lactobacillus, Staphylococcus, Streptococcus, and Microbacterium. Some genera were detected less frequently in raw milk such as Kocuria (Lafarge et al., 2004; Mallet et al., 2012; Hanamant and Bansilal, 2013) and Facklamia (Rasolofo et al., 2010, 2011).

According to Lafarge et al. (2004), L. lactis was the most frequently detected species in French raw milk samples, along with some Staphylococcus species. After incubation of the raw milk at $4^{\circ} \mathrm{C}$ for $24 \mathrm{~h}$, the majority of samples showed decreased representation of $L$. lactis and minority species such as Lactobacillus plantarum and Lactobacillus pentosus were outcompeted by other species. Despite a wide variance of the predominant groups found in raw milk after cold storage, Lafarge et al. (2004) noted an emergence of psychrotrophic bacteria such as Listeria spp. and Aeromonas hydrophila. Raats et al. (2011) examined the prevalence of Gram-positive and -negative bacteria in farm-collected raw milk samples and cold-stored dairy plant samples. The farm samples revealed a prevalence of Grampositive bacteria (bacilli, clostridia, and actinobacteria) while the dairy plant samples were characterized primarily by Gramnegative species (Gammaproteobacteria). In a $16 \mathrm{~S}$ rDNA based sequencing approach and despite variance in the predominant microbiota according to time and temperature of raw milk storage, Kable et al. (2016) demonstrated that raw milk microbial communities in tanker trucks in California (USA) were similar to each other even when samples were collected from different farms, transported to different locations and sampled at different times of the year. Surprisingly, these authors showed that the core microbiota (i.e., taxa present in all milk samples) of raw milk, consisting of 29 taxonomic groups, contained high proportions of Streptococcus and Staphylococcus and unidentified members of Clostridiales, but not Pseudomonas, which was present in relatively high proportions in some of the milk tested but entirely absent from two of the tankers examined. They also observed that Pseudomonas, along with psychrotrophic species of the genera Lactococcus, Streptococcus and Acinetobacter, tended to be present in relatively higher proportions in dairy plant silos than in the tanker trucks.

The psychrotrophic count, approximately $10 \%$ of the total count of mesophilic aerobes immediately after milking performed under hygienic conditions, may reach an average of 90\% after cold storage (Sørhaug and Stepaniak, 1997; Catanio et al., 2012). Rasolofo et al. (2010) noted that the biodiversity of raw milk microbiota decreased over the time of cold incubation 
TABLE 1 | Predominant bacterial groups found in fresh raw milk from different countries using culture-dependent and culture-independent methods.

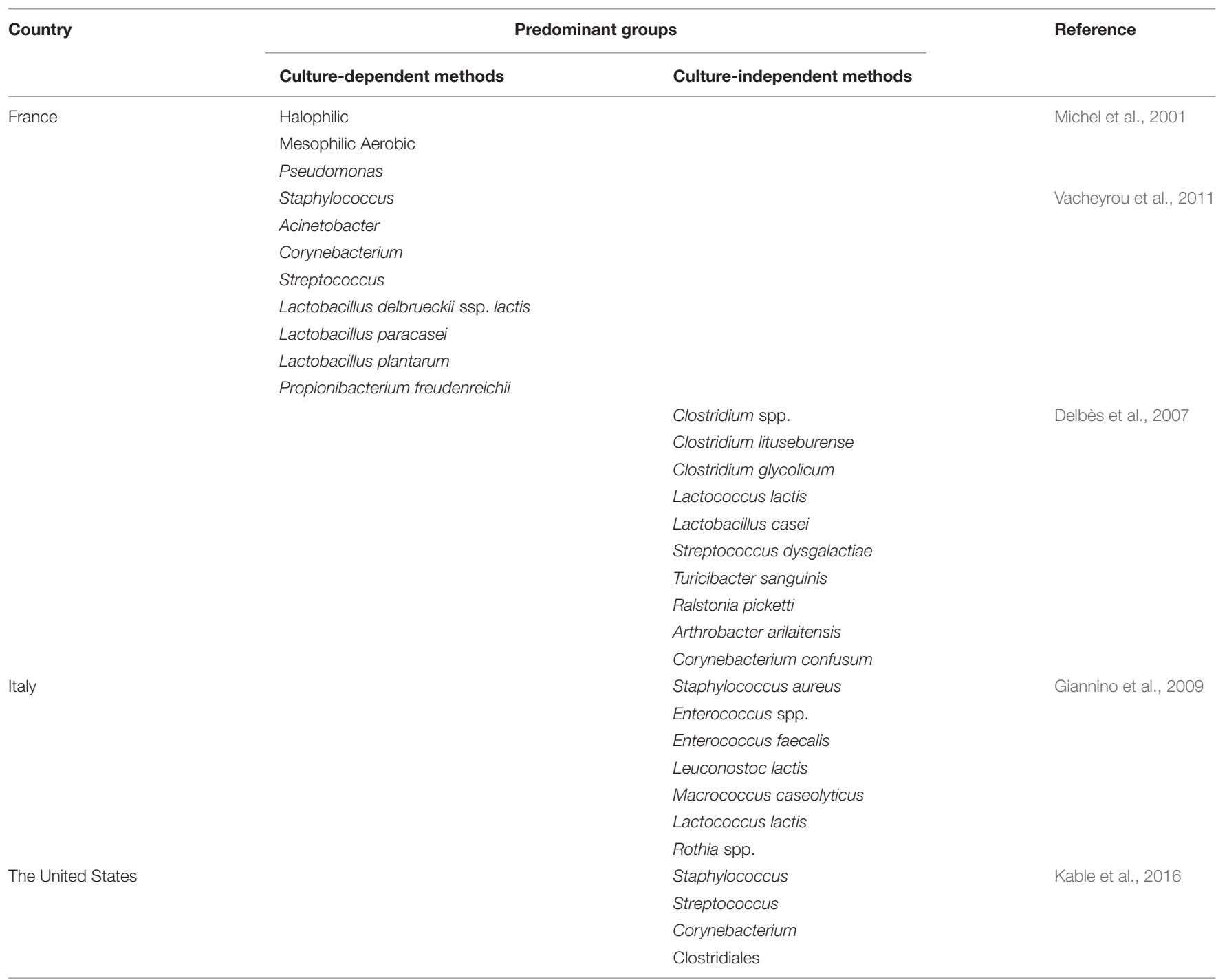

until psychrotrophic microbiota dominate. However, this group of cold-loving bacteria can represent more than $75 \%$ of the initial microbiota of raw milk when collected under conditions of poor hygiene (Hantis-Zacharov and Halpern, 2007; Malacarne et al., 2013).

\section{THE MILK SPOILAGE MICROBIOTA PRODUCING HEAT-STABLE ENZYMES}

While pasteurization inactivates most but not all of the bacteria found in raw milk, UHT treatment renders a product free of microorganisms in the vegetative state. However, several of the psychrotrophic microorganisms may secrete hydrolytic enzymes, which can be heat resistant from pasteurization up to UHT level. On the one hand, these hydrolytic enzymes may be an important tool for the food (dairy) industry as these enzymes may contribute to the development of cheese flavor and texture during ripening (Hasan et al., 2006; Tavano,
2013). On the other hand, the hydrolytic enzymes produced by psychrotrophic bacteria are also widely related to technological problems in milk and dairy products. Pseudomonas (mainly the P. fluorescens group), Bacillus, Serratia, and Hafnia have strong proteolytic potential while other species of Pseudomonas (mainly non-fluorescent pseudomonads), Bacillus, Enterobacter, and Acinetobacter are strongly lipolytic (Hantis-Zacharov and Halpern, 2007). According to the studies listed in Table 3, Pseudomonas is the predominant spoilage genus isolated from cold raw milk that secretes a heat-stable hydrolytic enzyme. This predominance has been detected at most sampling locations regardless of the approaches used for isolation and identification or time of milk storage.

Studies from the literature agree that Pseudomonas is the main genus related to milk spoilage, but within the genus, a diversity of the dominant hydrolytic Pseudomonas species isolated from milk samples is observed. Previous older studies focused on $P$. fluorescens, considered the main milk-spoilage species (Makhzoum et al., 1995; Liao and McCallus, 1998; 
TABLE 2 | Predominant bacterial groups found in raw milk samples in different countries using culture-dependent and culture-independent methods after cold storage.

\begin{tabular}{|c|c|c|c|c|}
\hline Country & \multicolumn{2}{|c|}{ Predominant groups } & Storage conditions & Reference \\
\hline \multirow[t]{4}{*}{ Algeria } & Stenotrophomonas rhizophila & & $4^{\circ} \mathrm{C}$ for 7 days & Boubendir et al., 2016 \\
\hline & Stenotrophomonas maltophilia & & & \\
\hline & Chryseobacterium indologenes & & & \\
\hline & Lactobacillus pentosus & & $4^{\circ} \mathrm{C}$ for 10 days & \\
\hline \multirow[t]{6}{*}{ Australia } & Pseudomonas fluorescens & & $2^{\circ} \mathrm{C}$ for 10 days & Vithanage et al., 2016 \\
\hline & Bacillus cereus & & & \\
\hline & Bacillus weihenstephanensis & & & \\
\hline & Bacillus circulans & & & \\
\hline & Pseudomonas & & $4-10^{\circ} \mathrm{C}$ for 10 days & \\
\hline & Microbacterium & & & \\
\hline \multirow[t]{9}{*}{ Brazil } & P. fluorescens & & $4^{\circ} \mathrm{C}$ for 2 days & Pinto et al., 2015 \\
\hline & Pseudomonas putida & & & \\
\hline & Pseudomonas stutzeri & & & \\
\hline & Serratia liquefaciens & & & \\
\hline & Serratia odorifera & & & \\
\hline & Bacillus amyloliquefaciens & & & \\
\hline & Bacillus subtilis & & & \\
\hline & Bacillus sp. & & & \\
\hline & Paenibacillus alvei & & & \\
\hline \multirow[t]{9}{*}{ Canada } & & Acinetobacter sp. & $4^{\circ} \mathrm{C}$ for 3 days & Rasolofo et al., 2010 \\
\hline & & Acinetobacter calcoaceticus & & \\
\hline & & Staphylococcus aureus & & \\
\hline & & Staphylococcus equorum & & \\
\hline & & Facklamia tabacinasalis & & \\
\hline & & Enterococcus faecium & & \\
\hline & & Lactococcus lactis & & \\
\hline & & Streptococcus uberis & & \\
\hline & & Pseudomonas fluorescens & $4^{\circ} \mathrm{C}$ for 7 days & \\
\hline \multirow[t]{9}{*}{ France } & Staphylococcus haemolyticus & & $2-4^{\circ} \mathrm{C}$ for $24-48 \mathrm{~h}$ & Mallet et al., 2012 \\
\hline & Staphylococcus aureus & & & \\
\hline & Staphylococcus saprophyticus & & & \\
\hline & Staphylococcus hominis & & & \\
\hline & Staphylococcus epidermidis & & & \\
\hline & L. lactis & & & \\
\hline & Enterococcus faecalis & & & \\
\hline & Kocuria rhizophila & & & \\
\hline & Stenotrophomonas maltophilia & & & \\
\hline
\end{tabular}




\begin{tabular}{|c|c|c|c|c|}
\hline \multirow[t]{2}{*}{ Country } & \multicolumn{2}{|c|}{ Predominant groups } & \multirow[t]{2}{*}{ Storage conditions } & \multirow[t]{2}{*}{ Reference } \\
\hline & Culture-dependent methods & Culture-independent methods & & \\
\hline & Acinetobacter johnsonii & & & \\
\hline & Pseudomonas & & $5^{\circ} \mathrm{C}$ for $24-48 \mathrm{~h}$ & Richard and Houssu, 1983 \\
\hline & Fravobacter-Cytophaga & & & \\
\hline & Coliforms & & $8-12^{\circ} \mathrm{C}$ for $24-48 \mathrm{~h}$ & \\
\hline & Pseudomonas & & & \\
\hline & Pseudomonas & & $4^{\circ} \mathrm{C}$ for $24 \mathrm{~h}$ & Desmasures et al., 1997a \\
\hline & Lactococci & & & \\
\hline & Micrococcaceae & & & \\
\hline \multirow[t]{3}{*}{ Germany } & Pseudomonas proteolytica & & $4-5^{\circ} \mathrm{C}$ for $3-4$ days & von Neubeck et al., 2015 \\
\hline & L. lactis & & & \\
\hline & Acinetobacter sp. nov. & & & \\
\hline \multirow[t]{3}{*}{ Israel } & & Pseudomonas & $4^{\circ} \mathrm{C}$ for $22-102 \mathrm{~h}$ & Raats et al., 2011 \\
\hline & & Acinetobacter & & \\
\hline & & Staphylococcus & & \\
\hline \multirow[t]{4}{*}{ The United States } & Pseudomonas & & $7^{\circ} \mathrm{C}$ for $12-18 \mathrm{~h}$ & Jayarao and Wang, 1999 \\
\hline & Klebsiella & & & \\
\hline & Enterobacter & & & \\
\hline & Escherichia & & & \\
\hline \multirow[t]{2}{*}{ Tunisia } & Pseudomonas & & $4^{\circ} \mathrm{C}$ for $24-96 \mathrm{~h}$ & Mankai et al., 2003 \\
\hline & Aeromonas & & & \\
\hline
\end{tabular}

$\mathrm{NI}$ - The storage conditions were not informed.

Matselis and Roussis, 1998; Ahn et al., 1999; Kumeta et al., 1999; Woods et al., 2001). However, the taxonomy of the genus Pseudomonas is very complex and many new species have been described in the $P$. fluorescens group for which phenotypic methods lack discriminatory power, so the role of $P$. fluorescens in milk spoilage has been overestimated (Marchand et al., 2009a). Even with the application of the sequencing of $16 \mathrm{~S}$ rDNA and housekeeping genes $(r p o B, g y r B)$ and comparison with an up to date in house database for Pseudomonas, a recent study on different food matrices could not identify all isolates to the exact species status with many of them classified as closely related to a known species (referred to as the species name + '-like') (Caldera et al., 2016). In that study, besides the species $P$. fragi(-like) and $P$. gessardii-like known as milk spoilers (Marchand et al., 2009b; De Jonghe et al., 2011), several other species as $P$. proteolytica, $P$. brenneri, and $P$. rhodesiae were found in raw milk, and $P$. peli-like in pasteurized milk. Mostly after applying cultureindependent methods for identifying the spoilage microbiota, other species belonging to Pseudomonas genus have been identified and characterized (von Neubeck et al., 2016). The peptidase producer Pseudomonas lundensis was isolated from raw milk samples from Belgium (Marchand et al., 2009a,b), from Germany (von Neubeck et al., 2015) and from Brazil (Machado et al., 2015). Two novel species, Pseudomonas helleri and Pseudomonas weihenstephanensis, isolated from cow milk, were characterized based on genetic, phylogenetic, chemotaxonomic, physiological, and biochemical data (von Neubeck et al., 2016). Other studies have demonstrated the (UHT) heat resistance of enzymes produced by $P$. weihenstephanensis, Pseudomonas proteolytica, and Pseudomonas panacis (Baur et al., 2015b; Stoeckel et al., 2016a).

Acinetobacter (like Pseudomonas also member of Gammaproteobacteria) is frequently detected in cold raw milk samples (Table 2). Strains belonging to this psychrotrophic genus may produce enzymes (Snellman et al., 2002; Salwan and Kasana, 2013) which could potentially lead to milk spoilage. Although some studies have detected hydrolytic strains of Acinetobacter in raw milk samples (Nörnberg et al., 2010; von Neubeck et al., 2015; Vithanage et al., 2016), the heat resistance of these enzymes and the spoilage potential from this genus is not well characterized and requires further investigation. Chryseobacterium (previously classified in Flavobacterium) also appears as a dominant member of Algerian cold raw milk (Table 2) and some species like Chryseobacterium joostei have been described recently as showing an even greater spoilage capacity than $P$. fluorescens in milk on the basis of growth rate, proteolytic and lipolytic activity (Bekker et al., 2015, 2016). However, besides proteolytic enzymes being resistant to pasteurization, resistance of these enzymes to UHT is not known.

The wide biodiversity of the microbiota of cold raw milk has led to less frequent reporting of several spoilage species. Although the predominance of Pseudomonas is well known, the importance of Serratia has been described more recently. Along with strains belonging to Pseudomonas, Serratia was also detected and characterized as a predominant milk spoiler in Australian, Brazilian, and Italian samples (Table 3). Teh et al. (2011) and Cleto et al. (2012) have detected Serratia in milk-processing plants and raw milk road tankers, respectively, while Lo et al. 
(2016) reported that $P$. fluorescens and Serratia were responsible for spoilage of raw milk stored at $4^{\circ} \mathrm{C}$ for 7 days. Lo et al. (2016) also showed that Serratia was slightly more dominant than $P$. fluorescens (50\% vs. $42 \%$ ) in a raw milk sample collected in a small Australian farm during the autumn. Besides Serratia, other psychrotrophic bacteria belonging to Enterobacteriaceae have been isolated from cold raw milk and have been identified as potential milk spoilers due to heat-resistant enzymes. Tondo et al. (2004) described the extensive coagulation of milk proteins after incubation with the heat-resistant peptidase of Klebsiella oxytoca. Other examples of the enteric group often detected in raw milk samples are H. alvei, Hafnia paralvei, and Enterobacter aerogenes, which are not only predominant species in raw milk, but also the most enzymatically active genera (Chen et al., 2011; Vithanage et al., 2016).

Although spoilage microbiota in raw milk is mostly Gram-negative and psychrotrophic, some Gram-positive genera have been highlighted, including Bacillus, Paenibacillus (both containing psychrotrophic members) as well as thermophilic Geobacillus. Paenibacillus polymyxa, B. cereus, B. licheniformis, and Bacillus subtilis are frequently linked to milk spoilage (Ternström et al., 1993; De Jonghe et al., 2010; Hanamant and Bansilal, 2012; Ranieri et al., 2012; Gopal et al., 2015) together with Geobacillus thermoleovorans and Geobacillus stearothermophilus (Sadiq et al., 2016). According to De Jonghe et al. (2010) and Sadiq et al. (2016), they are the producers of spoilage enzymes more particularly heat-stable lipase (Vithanage et al., 2016) that may adversely affect the quality of milk powder and dairy products made with milk powder (Chen et al., 2003). At refrigeration temperatures (e.g., $5-7^{\circ} \mathrm{C}$ ), spores without heat activation do not germinate and remain stable in milk (De Jonghe et al., 2010) and unless vegetative cells are present in biofilms on the milking or dairy equipment with the release of spoilage enzymes prior to heat treatment (Chen et al., 2004), it is questionable whether these spore formers play a role in spoilage of milk with long shelf life.

\section{HEAT-STABLE SPOILAGE ENZYMES PRODUCED BY PSYCHROTROPHIC MICROORGANISMS}

In general, the majority of psychrotrophic microorganisms isolated from milk have the ability to produce hydrolytic enzymes that break down the major milk constituents such as protein, fat and lecithin (Sørhaug and Stepaniak, 1997; Baur et al., 2015a; von Neubeck et al., 2015). Several peptidases, lipases and phospholipases produced by psychrotrophic bacteria isolated from milk have been described in the literature (Sørhaug and Stepaniak, 1997; Chen et al., 2003; Samaržija et al., 2012). Many of these hydrolytic enzymes are heat resistant and consequently retain part of their activity after conventional heat treatment applied in dairy industries such as pasteurization and UHT treatment. Regarding quality and economic aspects, the thermostable hydrolytic enzymes have the most significant effect in dairies since these enzymes lead to flavor defects and

TABLE 3 | Predominant spoilage species isolated from cold raw milk using culture-dependent and culture-independent methods.

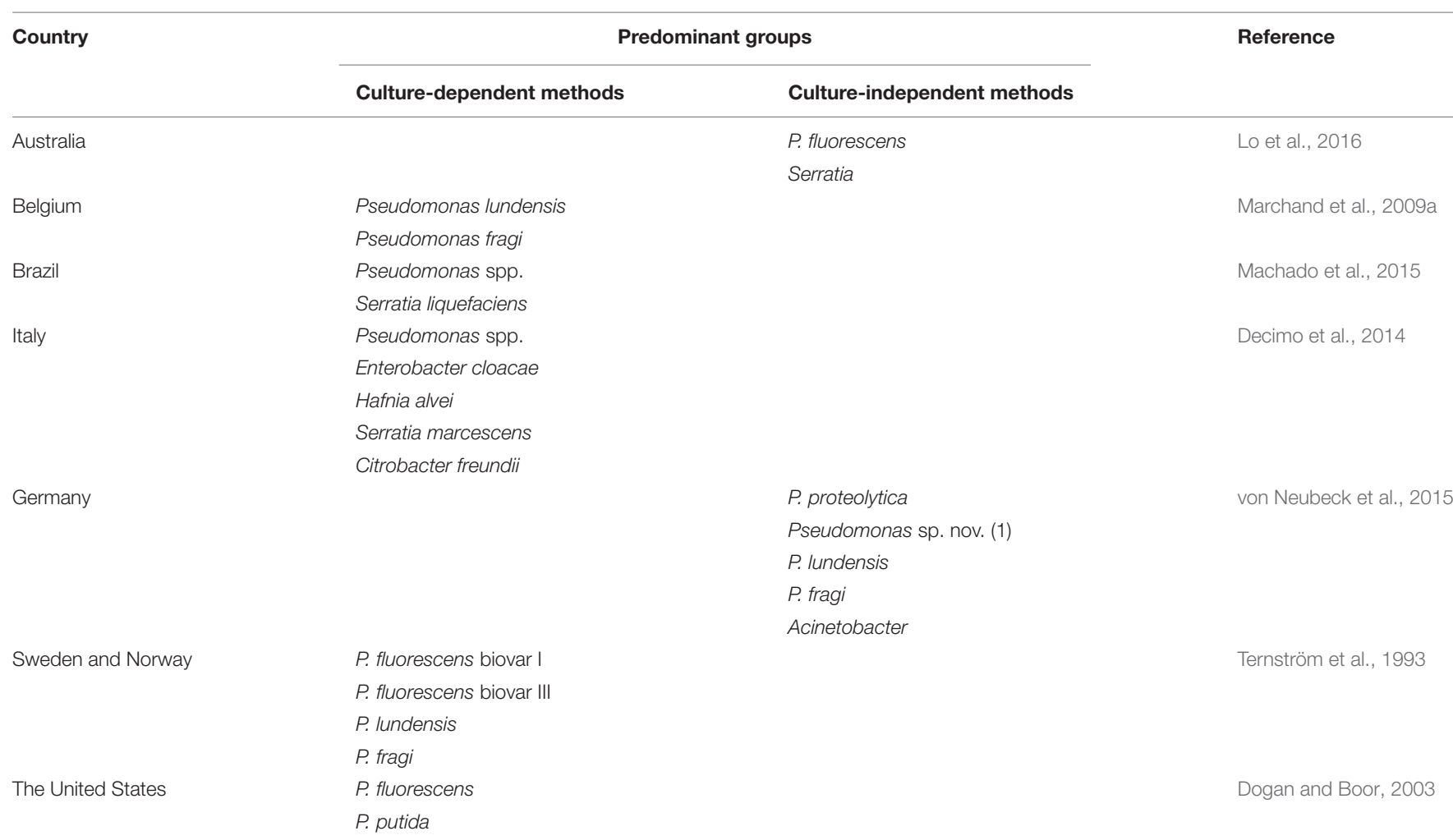


technological problems such as sedimentation and gelation in UHT milk, rancidity and flavor defects in milk powder and cheese during their shelf life (Sørhaug and Stepaniak, 1997).

\section{The Main Proteolytic Enzymes Found in Raw Milk}

The term proteolytic enzyme includes all the hydrolases that act on proteins, or further degrade the fragments of them. A few synonyms of proteolytic enzymes such as peptide-bond hydrolase, peptidase or protease could be found in the literature albeit the International Union of Biochemistry and Molecular Biology (IUBMB) recommend the term peptidase (Barrett, 2001). The main problem of the peptidases secreted by psychrotrophic bacteria is that they are heat-stable, which means that they resist at least pasteurization but it is not always described to what extent these enzymes also resist the higher temperatures of UHT.

AprX is the most studied heat-stable peptidase produced by the microbiota found in raw milk, although other species isolated from milk samples may also produce peptidases different from AprX, such as Klebsiella oxytoca (Tondo et al., 2004) or Serratia liquefaciens (Decimo et al., 2014). Bacillus spp. show more diverse proteolytic activity than Pseudomonas spp., and many species may secrete more than one type of extracellular and intracellular peptidase (Nabrdalik et al., 2010). The majority of heat-stable spoilage peptidases found in milk samples maintained at refrigeration conditions are produced by Gram-negative bacteria. This section therefore focuses on heat-stable peptidases from Pseudomonas and Serratia.

\section{Peptidase from Pseudomonas Isolated from Milk and Dairy Products}

The misidentification within the $P$. fluorescens group and an overestimation of the relevance of $P$. fluorescens in milk and dairy products spoilage has led to a large number of works focused on purification and characterization of heat-resistant peptidase produced by the so-called species P. fluorescens (Azcona et al., 1989; Kohlmann et al., 1991; Kim et al., 1997; Liao and McCallus, 1998; Matselis and Roussis, 1998; Costa et al., 2002; McCarthy et al., 2004; Maunsell et al., 2006; Dufour et al., 2008; Mu et al., 2009; Martins et al., 2015; Zhang et al., 2015). Although acknowledging this problem, the species name as described in the, respectively, cited literature will be retained in this review.

The number of the different peptidases produced by the genus Pseudomonas is heterogeneous and varies according to the species and the strains (Nicodème et al., 2005). Most of the studies mentioned in the paragraph above show that the strains of Pseudomonas spp. isolated from raw milk secrete at least one monomeric peptidase with molecular weight varying between 23 and $56 \mathrm{kDa}$. The metallopeptidase AprX is the main heatresistant peptidase in the genus Pseudomonas related to milk spoilage targeted in the literature (Liao and McCallus, 1998; Dufour et al., 2008; Marchand et al., 2009b; Baglinière et al., 2013; Martins et al., 2015). This enzyme is mainly secreted by the species $P$. fluorescens, but this peptidase has also been detected in various other species found in raw milk belonging to the genus Pseudomonas such as P. fragi, P. tolaasii, P. rhodesiae, P. gessardii,
P. proteolytica, P. brenneri, or P. chlororaphis (Martins et al., 2005; Marchand et al., 2009b; Caldera et al., 2016). Although no aprX sequence has yet been obtained, $P$. lundensis produces a similar enzyme, as evidenced by a few peptides of $P$. lundensis retrieved by mass spectrometry, which display similarity with the other Pseudomonas AprX proteases (Marchand et al., 2009b).

AprX is a peptidase of 45 to $50 \mathrm{kDa}$ encoded by the aprX gene located on the $\operatorname{aprX-lipA}$ operon, which contains eight genes and spans $14 \mathrm{~kb}$ (McCarthy et al., 2004). In general, AprX is rich in alanine and glycine residues and poor in cysteine and methionine residues (Dufour et al., 2008). The lack of cysteine residues allows avoidance of steric constraints due to disulphide bonds and increases its flexibility (Matéos et al., 2015). The presence of $\mathrm{Ca}^{2+}$ (GGXGXDXUX) and $\mathrm{Zn}^{2+}$ (HEIGHTLGLAHP) binding motifs confirms its dependence of divalent-cations (Dufour et al., 2008). The AprX protein is highly conserved within Pseudomonas species (76-99\% similarity for AprX of $P$. fluorescens group), but is more heterogeneous between species $(57-69 \%$ similarity for AprX between strains of $P$. fluorescens and $P$. fragi) (Marchand et al., 2009b; Matéos et al., 2015). In addition to the four AprX sequence groups (with one group split into two subgroups) identified within Pseudomonas raw milk isolates by Marchand et al. (2009b), a fifth group was added recently including Mozzarella isolates (Caldera et al., 2016).

AprX exhibits activity in a large range of $\mathrm{pH}(4.5-10)$ with an optimum activity between 7.5 and 9 , which proves that AprX is an alkaline peptidase. AprX generally exhibits activity in a large range of temperatures $\left(0-55^{\circ} \mathrm{C}\right)$ with optimal activity between 37 and $47^{\circ} \mathrm{C}$ (Dufour et al., 2008; Martins et al., 2015; Matéos et al., 2015). Inhibition studies revealed that AprX was inhibited by typical divalent-ion chelators such as EDTA $\left(\mathrm{Ca}^{2+}\right.$ and $\mathrm{Zn}^{2+}$ chelator), EGTA $\left(\mathrm{Ca}^{2+}\right.$ chelator), o-phenanthroline $\left(\mathrm{Zn}^{2+}\right.$ chelator) while serine peptidase inhibitors (PMSF and leupeptin) did not affect activity of the enzyme (Liao and McCallus, 1998; Dufour et al., 2008; Matéos et al., 2015). It was shown for an alkaline metallopeptidase isolated from a Pseudomonas sp. isolated from refrigerated milk, that $\mathrm{Ca}^{2+}$ stabilizes the enzyme and improves its activity (Ertan et al., 2015), while $\mathrm{Zn}^{2+}$ is essential in the active site (Wu and Chen, 2011).

AprX may hydrolyze the four types of casein $\left(\alpha_{s 1}, \alpha_{s 2}\right.$, $\beta$, and $\kappa$ ) with a large activity spectrum (Baglinière et al., 2013). Matéos et al. (2015) have shown that cleavage sites are mainly found in hydrophobic areas of casein. The extracellular peptidase produced by $P$. fluorescens hydrolyzes milk caseins preferentially in the following order $\kappa^{-}>\beta->\alpha_{S_{1}}$-caseins (Fairbairn and Law, 1986; Mu et al., 2009; Pinto et al., 2014; Zhang et al., 2015). However, Baglinière et al. (2012) described the preferential proteolysis of $\beta$-casein by AprX. This difference in preferential proteolysis between the different studies could be attributed to the differences in the species and strain used. In Figure 1, a hypothetical mechanism of UHT milk destabilization due to casein micelle proteolysis by heat-resistant protease during storage at ambient temperature is shown. The intensity of proteolytic activity is dependent on species and strains. Marchand et al. (2009a) and Baglinière et al. (2012) revealed a large heterogeneity, respectively, in the proteolytic activity within the Pseudomonas genus and in effect 


\section{UHT milk}

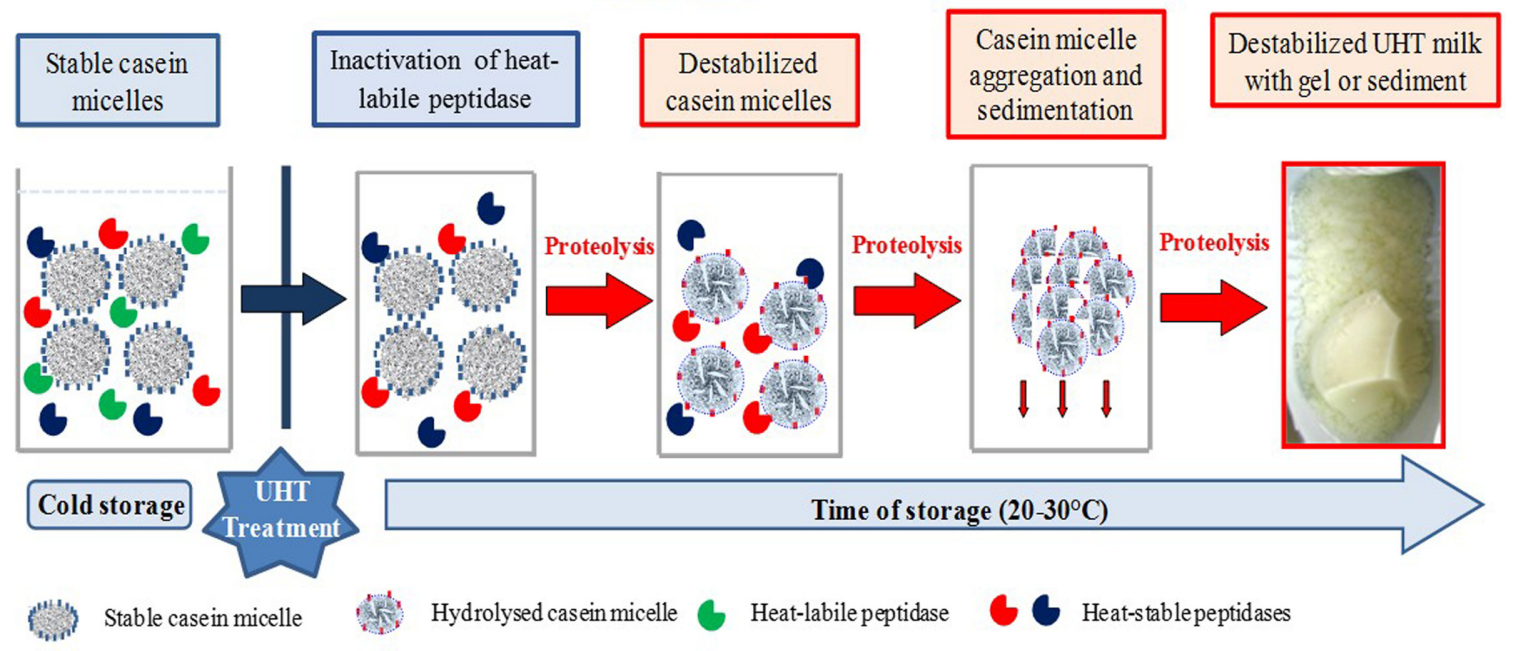

FIGURE 1 | Hypothetic mechanism of UHT milk destabilization due to casein micelle proteolysis by heat-resistant peptidase during storage at ambient temperature. The different species and strains of proteolytic psychrotrophic bacteria may produce heat-stable peptidases, which hydrolyze different types of casein. Some heat-resistant peptidases have preferential cleavage sites in hydrophobic areas of casein (red areas) while others hydrolyze preferentially the $\kappa$-casein which makes the connection between the hydrophobic core and the hydrophilic medium (blue areas).

on destabilization and flavor defects of UHT milk inoculated with P. fluorescens strains and other Pseudomonas species. Caldera et al. (2016) observed a high total proteolytic activity (without prior heat treatment) for all $P$. proteolytica isolates (4 and $12 \mu \mathrm{mol}$ glycine equivalent/mL, (as measured with the 2,4,6trinitrobenzenesulfonic acid [TNBS] method), the major part of $P$. gessardii-like isolates ( 2 and $16 \mu \mathrm{mol}$ glycine equivalent $/ \mathrm{mL}$ ), and for $36 \%$ of $P$. fragi(-like) isolates (5 and $14 \mu \mathrm{mol}$ glycine equivalent $/ \mathrm{mL}$ ). The high variability of Pseudomonas strains regarding the proteolytic activity may be a consequence of heterogeneous enzyme expression, regulation by quorum sensing (QS), effect of temperature, iron content, and bacterial growth phase (Woods et al., 2001; Nicodème et al., 2005; Marchand et al., 2009a).

Although AprX has been reported as the main heat-stable peptidase encountered in Pseudomonas spp. isolated from raw milk in several recent studies (Marchand et al., 2009b; Baglinière et al., 2013; Matéos et al., 2015), some authors showed that $P$. panacis and also $P$. fluorescens can secrete another heatstable peptidase AprA (Maunsell et al., 2006; Baur et al., 2015b). According to Baur et al. (2015b), the peptidase AprA secreted by a strain of $P$. panacis isolated from raw milk was able to withstand a UHT process. In the same study, the authors showed that the peptide sequence of AprA was 98\% similar to the peptidase AprX secreted by a strain of $P$. fluorescens. As AprX, AprA is a metallopeptidase of about $50 \mathrm{kDa}$ belonging to the serralysin family and presents in its primary structure the binding motifs for $\mathrm{Ca}^{2+}$ and $\mathrm{Zn}^{2+}$ (Takahashi, 2013; Baur et al., 2015b). According to Ma et al. (2003), there is a nomenclatural problem in the Apr protease system of Pseudomonas. According to those authors, AprA should be considered the main alkaline peptidase and AprX, lacking both the conserved $\mathrm{Zn}^{2+}$ binding sequence and the glycine-rich motif of AprA, is produced together with AprA by $P$. aeruginosa. However, the alkaline metalloprotease of $P$. fluorescens responsible for milk spoilage was first described as AprX by Dufour et al. (2008) and has been named as such in most studies since then. AprA and AprX produced by the Pseudomonas strains responsible for milk spoilage are the same enzyme because of their high sequence similarity and presence of the conserved motifs, while AprX produced by $P$. aeruginosa is a different enzyme.

A recent study conducted by Stuknytë et al. (2016) detected two other thermostable proteolytic bands with molecular masses of approximately 15 and $25 \mathrm{kDa}$ after zymography analysis from P. fluorescens PS19 supernatant. The $25-\mathrm{kDa}$ fragment did not show homology to AprX, indicating that this strain is able to secret a heat-stable peptidase other than AprX or AprA.

\section{Heat-Stable Peptidase from Serratia Isolated from Milk and Dairy Products}

The importance of Serratia as a milk-spoilage microorganism has been shown recently (Cleto et al., 2012; Decimo et al., 2014; Machado et al., 2015), although previous studies have described and/or characterized peptidases from S. proteamaculans (Christensen et al., 2003; Demidyuk et al., 2006; Eom et al., 2014), S. marcescens (Matsumoto et al., 1984; Letoffe et al., 1991; Jayaratne, 1996; Romero et al., 2001; Tao et al., 2007; Nam et al., 2013) and Serratia sp. E-15 (Hamada et al., 1996).

The number of peptidases produced by Serratia is variable. This characteristic could either be species dependent or variable, depending on the method used for peptidase detection. According to Matsumoto et al. (1984), S. marcescens kums3958 produced four peptidases as detected by polyacrylamide gel electrophoresis. These peptidases presented a molecular weight 
of 56, 60, and $73 \mathrm{kDa}$ wherein the $73 \mathrm{kDa}$-peptidase has been separated in two peptidases after isoelectric focusing. Nevertheless, Romero et al. (2001) detected only two peptidases when $S$. marcescens was inoculated into reconstituted whey. The molecular masses of both peptidases estimated on SDS-PAGE were 53.5 and $66.5 \mathrm{kDa}$ for the metallopeptidase and the serine peptidase, respectively. Those authors did not detect the $73 \mathrm{kDa}-$ peptidase. This result could be explained by the different growth conditions and strains used.

The metallopeptidase from S. marcescens S3-R1, which has a molecular weight of approximately $50.3 \mathrm{kDa}$, has been characterized by Nam et al. (2013). Those authors showed that this peptidase presents its optimal activity at $\mathrm{pH} 7-9$ and at $40-50^{\circ} \mathrm{C}$.

Unfortunately, there is no information in the literature about the characterization of the heat-stability of these peptidases. However, Glück et al. (2016) observed, for two strains of S. marcescens isolated from raw milk, an extracellular peptidase residual activity of 71 and $91 \%$ after a heat-treatment of $95^{\circ} \mathrm{C}$ for $5 \mathrm{~min}$, highlighting the secretion of heat-stable peptidase by this species. Nevertheless, the authors did not identify the peptidase responsible for this residual activity. Worth noting is that $S$. marcescens is an opportunistic pathogen for human and insects (Ishii et al., 2014; Hagiya et al., 2016), which justifies most studies focused on peptidases produced by this species, while the characterization of $S$. liquefaciens peptidases have been discussed by few authors only (Kaibara et al., 2010, 2012; Machado et al., 2016).

Serratia liquefaciens FK01 produces two serralysin-like metallopeptidases (Kaibara et al., 2010, 2012). These peptidases are encoded by ser 1 and ser 2 genes. Both peptidases showed molecular mass of approximately $50 \mathrm{kDa}$ and presented $\mathrm{Zn}^{2+}$ binding motif (HEXXHXUGUXH), $\mathrm{Ca}^{2+}$ binding motif (GGXGXDXUX), and ABC exporter motif (DXXX) (Kaibara et al., 2010, 2012; Machado et al., 2016). The difference between both peptidases produced by $S$. liquefaciens seems to be heat resistance. According to Machado et al. (2016), only Ser2 withstood the heat treatment of $95^{\circ} \mathrm{C}$ for $8: 45 \mathrm{~min}$. Those authors highlighted that proteolytic activity of Ser2 was highly variable depending on the incubation conditions and on the S. liquefaciens strain inoculated into the milk samples.

\section{Technological Problems Resulting from the Residual Activity of Peptidases after Heat Treatment}

Heat-resistant peptidases can lead to serious problems for the dairy industry. Since Pseudomonas has been widely studied, there are several studies focused on technological problems caused by peptidases from Pseudomonas (Celestino et al., 1997; Sørhaug and Stepaniak, 1997; Belloque et al., 2001; Datta and Deeth, 2001, 2003; Chen et al., 2003; Baglinière et al., 2013), however, there are no studies yet regarding the consequences of peptidase from Serratia in dairy products.

After raw milk storage for prolonged time, UHT processing can be compromised because of destabilization of the milk, resulting in clogging of the heating exchanger (Figure 2). Pinto et al. (2014) showed that $\alpha$-, $\beta$-, and $\kappa$-casein from milk inoculated with $P$. fluorescens were completely hydrolyzed after 4 days incubation at $4^{\circ} \mathrm{C}$. The proteolysis of casein contributes to destabilization of UHT milk and to protein sedimentation during its storage (Gaucher et al., 2011; Baglinière et al., 2013; Matéos et al., 2015). A visual destabilization of UHT milk by AprX from $P$. fluorescens $\mathrm{F}$ was observed after 7 days of storage when $0.2 \mathrm{mg} / \mathrm{mL}$ of peptidase had been added in raw milk before UHT treatment (Baglinière et al., 2013). The protein sedimentation could be observed after 2 weeks of storage in UHT milk samples when peptidases from $P$. panacis where inoculated at a final concentration of 1 picokatal/mL (Baur et al., 2015b; one katal of an enzyme is that amount which breaks a mole of peptide bonds per second under specified conditions).

The proteolysis of milk protein can also lead to bitter off-flavor of some dairy products such as UHT milk. This is caused by the generation of hydrophobic peptides by hydrolysis of casein (Chen et al., 2003; Datta and Deeth, 2003). Valero et al. (2001) showed that new flavor and volatile components appeared in skimmed milk samples after 65 days storage related to proteolysis and the Maillard reaction. The proteolytic activity might increase the number of free amino groups, which can participate with the reducing sugars in Maillard reactions (Valero et al., 2001). In UHT-milk spiked with one each of six isolates representing the different Pseudomonas peptidase groups, a casein hydrolysis of $>1.5 \mu \mathrm{mol}$ glycine equivalents/mL (as measured with the TNBS method) was the threshold for the taste panel to detect off-flavor, but no clear correlation was found between the onset of offflavors and the rate of protein hydrolysis (Marchand et al., 2017). The degree of proteolysis (as measured with the TNBS method) of the UHT-milk samples in which off-flavors were significantly tasted, were different for each Pseudomonas peptidase under evaluation (Figure 3). P. fragi peptidase was capable in generating off-flavors after very limited proteolysis (a raise in TNBS-value of 0.15 glycine equivalents $/ \mathrm{mL}$ ). Therefore, it can be speculated that not all Pseudomonas peptidases have the same specificity for their casein substrates.

However, a large difference in heat resistant or total proteolytic activity was observed within P. fragi by Marchand et al. (2009a) and Caldera et al. (2016), respectively, with only $36 \%$ of $P$. fragi(like) isolates (from diverse sources including dairy and raw milk) showing total proteolytic activity according to the latter authors. Nevertheless, when positive for proteolytic activity, the P. fragi group exhibited a significantly higher heat-resistant proteolytic activity than the P. lundensis and the Pseudomonas spp. group (Marchand et al., 2009a), which suggests that the presence of proteolytic strains of $P$. fragi prior to UHT-processing will severely compromise the shelf life of derived dairy products.

Another technological problem in the dairy industry caused by proteolytic activity from psychrotrophic microorganisms is the yield reduction in cheese manufacturing (Cardoso, 2006; Mankai et al., 2012). Cardoso (2006) showed a reduction of $6.38 \%$ in total solids in fresh Minas cheese produced using a raw milk stored for four days under cold temperatures, which promotes psychrotrophic growth.

\section{Lipolytic Enzymes}

Lipolytic enzymes in cow's milk from endogenous or exogenous sources and the action of these enzymes on the milk substrate is 

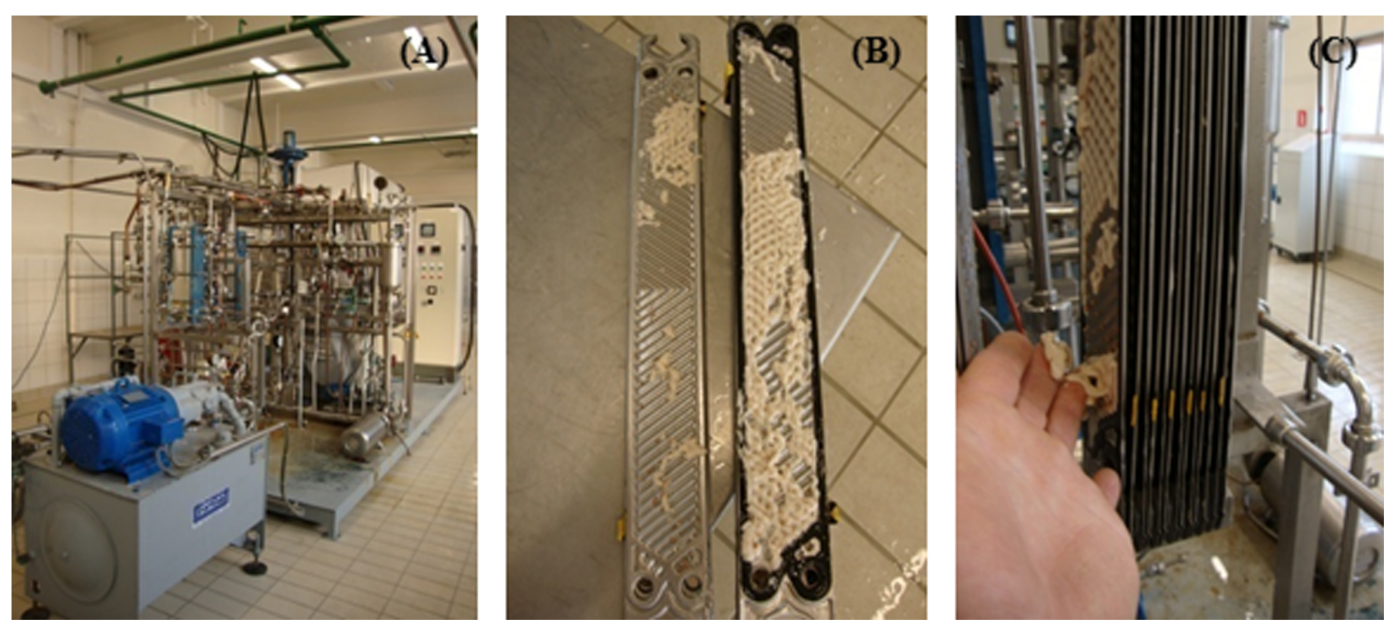

FIGURE 2 | Clogging of the heating exchanger due to processing of milk spiked with Pseudomonas and stored for 5 days at $6.5^{\circ} \mathbf{C}$. (A) UHT Process Pilot Plant (ILVO, Belgium), (B) heat exchanger, (C) detail of the heat exchanger with clotting of milk.

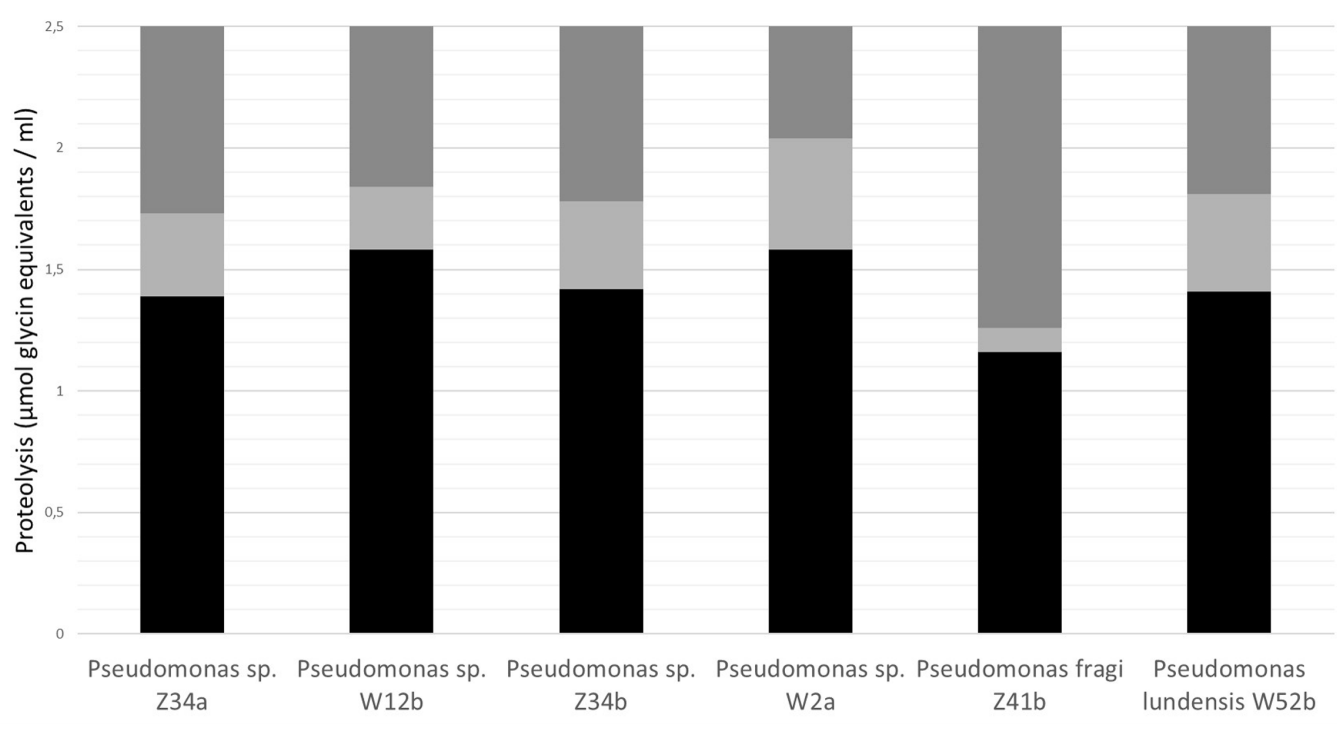

FIGURE 3 | Correlation between off-flavors and protein hydrolysis by six different Pseudomonas peptidase groups in UHT-milk, as described by Marchand et al. (2009b). Raw milk was pasteurized, inoculated with one of the Pseudomonas strains to a final concentration of 3 log CFU/mL, and stored for 3 to 5 days at $6.5^{\circ} \mathrm{C}$ until skimming and indirect UHT-processing $\left(5 \mathrm{~s}\right.$ at $\left.140^{\circ} \mathrm{C}\right)$. Processed milk was aseptically filled in high-density polyethylene bottles of $0.5 \mathrm{~L}$ and stored at $37^{\circ} \mathrm{C}$ to accelerate proteolysis. The six Pseudomonas peptidase milk samples were compared with the reference control milk by an experienced taste panel of 35 people at the Institute for Agricultural and Fisheries Research (ILVO), Belgium in a sensorial cabinet equipped with individually partitioned booths. Milk with off-flavor was diluted as follows: (A) Pseudomonas milk undiluted, (B) 2/3 Pseudomonas milk + 1/3 control milk, (C) 1/3 Pseudomonas milk + 2/3 control milk, (D) Control milk undiluted. The taste panel was asked to rank the milk samples (A-B-C-D) according to preference. Statistical evaluation of the results was based on the Rank Test to KRAMER (Kramer, 1960) for $\alpha=0.05$. Simultaneously, proteolysis (expressed as $\mu$ mol glycine equivalents $\mathrm{mL}^{-1}$ milk) was determined in each milk dilution (A-B-C-D) by the trinitrobenzenesulfonic acid (TNBS) method (Polychroniadou, 1988). No significant proteolysis off-flavors is indicated by black bars, the uncertainty range by light gray bars (the panel did not reject the milk samples; the lower limit of the bar is determined by the TNBS-value of the most diluted sample that was not rejected by sensory analysis) and the significant proteolysis off-flavors by dark gray bars (panel rejected the milk samples and tasted off-flavors; the lower limit of the bar is determined by the TNBS-value of the least diluted sample). This figure was reproduced from Marchand et al. (2017).

considered as limited by its natural organization in the form of fat droplets (Bourlieu et al., 2012). Undesirable lipolysis of milk and dairy products has not been studied as much as undesirable proteolysis. Exogenous lipases produced by psychrotrophic bacteria can hydrolyze milk fat and release free fatty acids (FFAs), mono- and di-acylglycerols and glycerol. The lipolytic activity of psychrotrophs is species-specific. According to Decimo et al. (2016) bacterial triacylglycerol hydrolysis may occur to a greater or lesser extent, but the type and amount of released FFAs are not easily predictable. The lipolytic activity generates undesirable 
product flavors such as rancid, unclean, soapy, or bitter, making the product barely acceptable to the consumer (Deeth, 2006).

Among the lipolytic psychrotrophic bacteria, Pseudomonas spp. is the predominant Gram-negative group found whereas Bacillus spp. is the predominant Gram-positive group (Chen et al., 2003; Decimo et al., 2014; Vithanage et al., 2016). However, other genera isolated from raw milk, may also produce lipolytic enzymes, such as Serratia, Hafnia, Acinetobacter, Microbacterium, and Enterobacter (Hantis-Zacharov and Halpern, 2007; Decimo et al., 2014; Vithanage et al., 2016).

Lipolytic enzymes are defined as carboxylesterases that hydrolyse acylglycerols (Jaeger et al., 1994, 1999; Chen et al., 2003). Carboxylesterases can be divided in two groups, the lipase or triacylglycerol acylhydrolases (EC 3.1.1.3) and the esterase or carboxylases (EC 3.1.1.1). Lipases are active at lipid-water interfaces rather than in the aqueous phase and preferentially hydrolyze acylglycerols with more than 10 carbons $\left(>\mathrm{C}_{10}\right)$. Esterases are active in aqueous solutions and are only able to hydrolyze acylglycerols with fewer than 10 carbons $\left(<\mathrm{C}_{10}\right)$ (Anthonsen et al., 1995). Lipase is also capable of hydrolyzing acylglycerols <C10 (Jaeger et al., 1994, 1999) and intact milk fat globules (MFG). Without hydrolysis of the fat globules, the lipolytic enzyme does not have access to triglycerides (Deeth, 2006). In terms of spoilage potential, this difference between lipase and esterase hydrolysis could explain most of the lipolytic enzymes studied are secreted lipase. Another enzyme able to hydrolyze MFG is phospholipase. However, this enzyme cannot hydrolyze triacylglycerol. Therefore, this review focuses on lipase secreted by the genera Pseudomonas and Bacillus, particularly heat-stable lipase.

\section{Lipase from Pseudomonas Isolated from Milk and Dairy Products}

Among the lipolytic species of Pseudomonas, P. fluorescens is the species more often found in raw milk. Nevertheless, some recent studies showed the presence of lipolytic strains of $P$. aeruginosa, P. putida, P. fragi, and P. gessardii-like in raw milk or P. pelilike in pasteurized milk (Munsch-Alatossava et al., 2013; Decimo et al., 2014; Caldera et al., 2016). Pseudomonas spp. produce a large variety of lipolytic enzymes classified into six groups corresponding to family and subfamily (Arpigny and Jaeger, 1999; Chen et al., 2003). However, most of lipases secreted by the species found in raw milk such as $P$. aeruginosa, $P$. fluorescens, and $P$. fragi belong to the sub families I.1 and I.3 (Arpigny and Jaeger, 1999). Most of them have specificity for the sn- 1 and sn-3 positions of triacylglycerols, and some hydrolyze diacylglycerols and monoacylglycerols faster than triacylglycerols (Chen et al., 2003). The classification of these enzymes is based on their amino acid homologies and some biological properties. These lipases present the consensus pentapeptide G-X-S-X-G in the amino acid sequence, corresponding to the catalytic site.

Subfamily I.1 corresponds to the secreted lipases with a molecular weight of approximately $30 \mathrm{kDa}$, which present two aspartic residues involved in the $\mathrm{Ca}^{2+}$ binding site (Arpigny and Jaeger, 1999). These lipases are mainly secreted by $P$. aeruginosa and P. fragi (Arpigny and Jaeger, 1999). However, the species $P$. fluorescens is also able to secrete a lipase belonging to this subfamily (Beven et al., 2001). Subfamily I.3 corresponds to lipase with a molecular mass of 50 to $65 \mathrm{kDa}$. The most studied lipase from this group is LipA from $P$. fluorescens encoded by the lipA gene located in the same operon as the peptidase AprX, the operon aprX-lipA. Similar to the peptidases Ser2 and AprX, this lipase presents in the amino acid sequences the binding motif to fix $\mathrm{Ca}^{2+}$ suggesting the need of this ion for its stability. The lipases of $P$. fluorescens 33 (Kumura et al., 1993a,b), P. fluorescens 041 (Martins et al., 2015), P. fluorescens SIK W1 (Son et al., 2012) isolated from milk and one of the lipases of P. fluorescens C9 (Beven et al., 2001) belong to this family.

Numerous older studies have shown the heat-stability of the lipolytic activity of Pseudomonas species. Law et al. (1976) showed that after a heat treatment of $63^{\circ} \mathrm{C}$ during $30 \mathrm{~min}$ in raw milk, the extracellular residual lipolytic activities of various strains of Pseudomonas isolated from raw milk were 55 to $100 \%$. FitzGerald et al. (1982) observed that lipases from Pseudomonas isolated from raw milk presented 75 to $100 \%$ of residual lipolytic activity after heating skim milk at $100^{\circ} \mathrm{C}$ for $30 \mathrm{~s}$. Moreover, Andersson et al. (1979) reported a $D$-value of $23.5 \mathrm{~min}$ (calculated time required for a $90 \%$ reduction of the initial activity) for P. fluorescens SIK W1 lipase after heat-treatment of skim milk at $100^{\circ} \mathrm{C}$. As described by Fox and Stepaniak (1983), lipase from Pseudomonas seems to be more heat-stable in synthetic milk salt solutions than in phosphate buffer. This better heat-stability in milk salt solutions is probably due to the presence of calcium (Andersson et al., 1979). Recent studies, however, show that not all lipases secreted by the genus Pseudomonas are heat-stable. The residual lipase activity of the purified LipM of P. fluorescens 041 isolated from Brazilian raw milk was only $25.4 \%$ after heattreatment of $72^{\circ} \mathrm{C}$ for $20 \mathrm{~s}$ in buffer (Martins et al., 2015). It is noteworthy that Vithanage et al. (2016) showed that more than $30 \%$ of Pseudomonas strains isolated from raw milk presented 50 to $75 \%$ of residual lipase activity after a heat treatment of $4 \mathrm{~s}$ at $142^{\circ} \mathrm{C}$ (UHT treatment). Those authors observed more strains producing heat-stable lipases than strains producing heat-labile lipases among Pseudomonas strain isolated from raw milk.

These studies confirm that many lipases from the genus Pseudomonas can resist heat-treatment used in dairy industries such as pasteurization and/or UHT treatment. No heat treatment is available that may inactivate these lipases without altering the milk's sensory and nutritional qualities.

\section{Lipase from Bacillus spp. Isolated from Milk and Dairy Products}

The presence of the thermophilic species Geobacillus stearothermophilus as a lipolytic enzyme producer in raw milk and milk powder has been reported by various authors (Chopra and Mathur, 1984, 1985; Chen et al., 2004). The principal characteristic of Bacillus lipases is the substitution of the first glycine by alanine in the conserved pentapeptide A-X-S-X-G (Arpigny and Jaeger, 1999). Most Bacillus lipases show the highest catalytic activities at temperatures ranging from 60 to $75^{\circ} \mathrm{C}$ (Chen et al., 2003). The lipase of Bacillus can be classified in two groups: subfamilies I.4 and I.5. The lipase of $B$. subtilis (molecular mass about $20 \mathrm{kDa}$ ) is the smallest true lipase known from bacteria found in raw milk (Arpigny 
and Jaeger, 1999). This lipase, belonging to subfamily I.4, is also secreted by $B$. licheniformis, frequently encountered in raw milk as a lipolytic enzyme producer (Baur et al., 2015a). With a molecular mass of $45 \mathrm{kDa}$, the lipase secreted by the species $G$. thermocatenulatus and G. stearothermophilus belongs to subfamily I.5 and shows optimal activity at pH 9.0 and $60-65^{\circ} \mathrm{C}$ (Schmidt-Dannert et al., 1996; Kim et al., 1998; Arpigny and Jaeger, 1999).

As described above for Pseudomonas, many Bacillus (or Geobacillus) lipases remain stable during heat-treatments used in dairy industries (pasteurization and/or UHT treatment) and can therefore affect milk and dairy products during storage. Chen et al. (2003) calculated a $t_{1 / 2}$ of $690 \mathrm{~min}$ at $70^{\circ} \mathrm{C}$ in buffer at $\mathrm{pH}$ 7.0 for the lipase produced by a strain of G. stearothermophilus. Considering all lipases secreted by Bacillus, lipases from strains isolated from milk powder production presented a higher residual activity after pasteurization at $72^{\circ} \mathrm{C}$ for $2 \mathrm{~min}$ in milk (Chen et al., 2004). In addition, a recent study showed that more than $38 \%$ of Bacillus strains isolated from raw milk presented 50 to $75 \%$ of residual lipase activity after a heat treatment at $142^{\circ} \mathrm{C}$ for $4 \mathrm{~s}$ (Vithanage et al., 2016).

\section{Phospholipase C}

The production of different phospholipases has been reported for Gram-negative and Gram-positive psychrotrophs (Sørhaug and Stepaniak, 1997). The phospholipase most studied is phospholipase $\mathrm{C}$, which can be either hemolytic or nonhemolytic. Phospholipase $\mathrm{C}$ activity has been detected in the genera Pseudomonas, Bacillus, Serratia, Hafnia, Acinetobacter, and Microbacterium in raw milk by Vithanage et al. (2016). However, according to De Jonghe et al. (2010), in the genus Bacillus only the species $B$. cereus is able to produce the phospholipase $C$. The presence of this enzyme was not observed for the species $B$. licheniformis or B. subtilis. This enzyme is particularly heat stable (Sørhaug and Stepaniak, 1997) and disrupts the integrity of the MFG membrane (Craven and Macauley, 1992; Shah, 1994).

The phospholipase C of P. fluorescens is well known as a heat-stable enzyme, presenting high residual activity after pasteurization and UHT treatment (Sørhaug and Stepaniak, 1997). Vithanage et al. (2016) observed that about $25 \%$ of Bacillus and Pseudomonas strains isolated from raw milk presented 50 to $75 \%$ of residual phospholipase $\mathrm{C}$ activity after heat-treatment of $140^{\circ} \mathrm{C}$ during $4 \mathrm{~s}$.

\section{Technological Problems Resulting from the Residual Activity of Lipases after Heat Treatment}

The presence of bacterial lipase could affect the quality of fluid milk, dry whole milk, cheese, and butter (Sørhaug and Stepaniak, 1997; Chen et al., 2003). However, it seems that the modifications induced to milk lipids are highly dependent on the lipase specificity and also on the fat condition. Excessive shaking, addition of air, repeated thermal shocks, and homogenization, all of which can occur at different stages of production and processing, adversely affect the integrity of the fat globule, modify the interfaces between the fat and non-fat phase and lead to an increase of lipolysis (Kim et al., 1983). The action of lipase on milk fat can release short-chain fatty acids (C4:0 to C8:0), medium-chain fatty acids (C10:0 and C12:0) and long-chain fatty acids (C14:0 to C18:0). Short-chain fatty acids (e.g., butyric, caprylic, and caproic acids) have strong flavors and can impart unpleasant flavors variously known as rancid, bitter, butyric, unclean, astringent, or 'lipase' (Deeth, 2011), whereas mediumchain fatty acids are responsible for a soapy taste (Chen et al., 2003). Long-chain fatty acids contribute little to flavor. Moreover, as described by Chen et al. (2003), an oxidized flavor can be generated by the oxidation of free unsaturated fatty acids to aldehydes and ketones. Due to presence of heat-stable lipases in raw milk, theses undesirable flavors, such as rancidity, can occur in UHT-milk (Adams and Brawley, 1981). The mono- and diacylglycerols which are the other products of lipase action have surface-active properties that can affect some products such as steam-foamed milk used in coffee-based drinks (Deeth, 2011).

Whole milk powder can be also affected by residual heatresistant lipase, because most enzymes are more stable when water activity decreases. Indeed, some authors showed that lipase of $P$. fluorescens in spray-dried powder did not lose activity at $20^{\circ} \mathrm{C}$ for up to 60 days (Shamsuzzaman et al., 1986). According to Andersson (1980), lipases retain more activity than peptidases in milk powder during prolonged storage. Moreover, residual lipase activities may be detected when dry whey products and skimmed milk powder are added as ingredients to fatty products (Stead, 1986).

\section{Lipase and Peptidase Regulation}

Understanding of the regulation of peptidases and lipases produced by psychrotrophic bacteria in milk samples is still limited. Compared to the other psychrotrophic genera, the regulation of enzymes secreted by the genus Pseudomonas has been the most studied, especially the operon aprX-lipA regulation. However, the complex production process of these two enzymes is not completely understood. The following section will be focused on the regulation of extracellular enzymes produced by the genus Pseudomonas. The factors involved in this regulation are described briefly.

Many factors are involved in the lipase and peptidase production by psychrotrophic bacteria, such as temperature (Burger et al., 2000; Nicodème et al., 2005), phase of growth (Chabeaud et al., 2001; van den Broeck et al., 2005), QS (Givskov et al., 1997; Christensen et al., 2003; Juhas et al., 2005; Liu et al., 2007; Pinto et al., 2007) or iron content (McKellar, 1989; Woods et al., 2001).

In $P$. fluorescens, enzyme production seems to be strongly related to cell density. According to Bai and Rai (2011), the production of extracellular peptidases in P. fluorescens is associated with the high cell density that is typically encountered at the end of the exponential phase of growth. One hypothesis is that this regulation by cell density may be mediated by QS. Indeed, bacteria may communicate by QS using signaling molecules called $N$-acyl-homoserine lactones (AHLs). These molecules are produced by numerous Gram-negative bacteria such as Pseudomonas (Liu et al., 2007) or Serratia (Givskov et al., 1997) and are implicated in the genetic control of a wide range of phenotypic attributes such as cell differentiation, 
biofilm formation, sporulation, toxins, and enzyme secretion (De Oliveira et al., 2015). Their production is strongly dependent on a specific cell density (Fuqua et al., 1994; Liu et al., 2007). A remarkable seasonal variation on heat resistant proteolytic activity of Pseudomonas strains from raw milk was observed (Marchand et al., 2009a). This effect could be related to growth rate: in milk samples with proteolytic bacteria, the proteolytic psychrotolerant counts were significantly higher in samples collected in winter than in summer and winter isolates displayed better growth characteristics and peptidase production than the summer isolates.

Pinto et al. (2007) showed that more than $80 \%$ of psychrotrophic proteolytic strains isolated from cooled raw milk were able to produce AHLs in raw milk and pasteurized milk, suggesting that QS may play a role in the spoilage of milk. Liu et al. (2007) reported that the proteolytic activity of the strain 395 of $P$. fluorescens was stimulated by the addition of AHL. Those authors concluded that the $\operatorname{aprX}$ gene was regulated at a transcriptional level by AHL during the end of the exponential phase of growth. In contrast, Pinto et al. (2010) did not observe any effect on the growth and proteolytic activity after adding synthetic AHL in the culture of the proteolytic strain P. fluorescens 07A that secretes AprX but does not produce AHL. The extracellular peptidase activity was detected only when the cell population reached $10^{8} \mathrm{CFU} / \mathrm{mL}$. They concluded that peptidase activity of this strain was not regulated by QS via AHLs but could be related to cell density. The regulation of enzyme production by QS via AHLs seems thus to be strain dependent in the species $P$. fluorescens. According to Siddiqui et al. (2005), in $P$. fluorescens CHA0, the expression of aprA gene seems to be also cell density dependent. In addition, the authors showed that the expression of this protease was positively regulated by the twocomponent system GacS/GacA, which controls the expression of secondary metabolism and protein secretion in a wide variety of bacterial species.

Relating to other genera implicated in milk spoilage, the relationship between QS, cell density and enzyme production has been observed among members of the Serratia genus. It seems that the operon slaA-lipB of S. proteamaculans, which is required for the secretion of several unrelated and potentially food-quality-relevant proteins and the exoenzyme production and its homolog in S. liquefaciens, is under the transcriptional control of QS (Givskov et al., 1997; Christensen et al., 2003). Christensen et al. (2003) demonstrated that the activities of several exoenzymes including peptidases from $S$. proteamaculans B5a are affected by $\mathrm{N}$-(3-oxo-hexanoyl)-L-homoserine lactone, which is a signal molecule of QS system in Gram-negative bacteria. Although Ser2 is a heat-resistant peptidase that may compromise milk product quality, no information about regulation of Ser2 expression is available.

Numerous studies show that the enzymes of $P$. fluorescens are regulated by the temperature of growth. Optimal peptidase production occurs when the temperature of growth is slightly above the optimal temperature of growth, while above this temperature peptidase production is severely repressed (Burger et al., 2000; Woods et al., 2001; McCarthy et al., 2004). In contrast, optimal lipase production occurs when the temperature of growth is well below the optimal growth temperature, suggesting the contribution of low temperature-dependent regulation system (Andersson, 1980; Merieau et al., 1993; Woods et al., 2001). However, a study carried out by Woods et al. (2001) showed that the temperature does not regulate AprX and LipA production at the transcriptional level (operon $a p r X$ lipA) suggesting that the regulation is post-transcriptional or post-translational.

Relating to mineral content, the expression of the aprX-lipA operon is negatively regulated at the transcriptional level by iron (III) (Woods et al., 2001). Moreover, McCarthy et al. (2004)

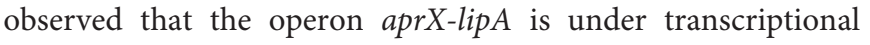
control of the two-component regulatory system homologous to the E. coli two-component system called EnvZ-OmpR. However, those authors observed that lipase production was more affected by this regulatory system than peptidase production. The distal locations between the genes $a p r X$ and $\operatorname{lip} A$ on the operon could explain that this difference of regulation may be related to their proximal and distal position, respectively, within the aprX-lipA operon (McCarthy et al., 2004).

\section{CONTROL OF SPOILAGE BY HEAT-RESISTANT BACTERIAL ENZYMES}

Reducing the activity and/or limiting the secretion of heatresistant hydrolytic enzymes of psychrotrophic bacteria is a scientific challenge. Once the enzymes are formed, reducing their activity by heating seems to be very difficult. A recent review (Stoeckel et al., 2016b) summarizes available data on inactivation of Pseudomonas proteases and proposes heat treatments that reduce the protease activity in the final product to entend the shelf life of UHT products. For UHT products intended for export, UHT heating combined with prolonged preheating (e.g., $90-95^{\circ} \mathrm{C}$ for $180-90 \mathrm{~s}$ ) is suggested to reduce $99.99 \%$ of the indigenous milk plasmin activity. Pseudomonas proteases show also an irreversible low temperature inactivation behavior due to unfolding of the tertiary structure of the enzyme at a temperature range of $45-65^{\circ} \mathrm{C}$, rendering it susceptible to autoproteolysis. This inactivation was recently shown between 42 and $48^{\circ} \mathrm{C}$ for a new broad specificity metalloprotease from a Pseudomonas spp. isolated from refrigerated milk (Ertan et al., 2015). However, this effect seems much lower in milk compared to buffer systems because of protective effects of milk components, and thus a low preheating step is not effective to sufficiently reduce this bacterial proteolytic activity. The development of other heating processes (e.g., heat-treatment at $125-130^{\circ} \mathrm{C}$ ) for long holding times (>150 s) has been suggested (Stoeckel et al., 2016b). However, such treatment may result in color changes and degradation of lysin, thiamin, and riboflavin (Kessler, 1996).

Another option for spoilage control is to prevent the production of heat-resistant enzymes by limiting the growth of psychrotrophic bacteria in raw milk. This could be realized by modifying the composition of the atmosphere surrounding the milk. $\mathrm{N}_{2}$ gas flushing of cold-stored raw milk $\left(6^{\circ} \mathrm{C}\right)$ has been shown to strongly inhibit bacterial growth (Gschwendtner et al., 2016), as 3-4 log fewer bacteria were counted after 
7 days compared to non-flushed milk. Furthermore, analysis of the bacterial population by next generation sequencing (NGS) of 16S rRNA transcripts showed a relatively lower number of Pseudomonas reads in the $\mathrm{N}_{2}$ gas flushed milk, indicating selective inhibition of Pseudomonas growth. Changing the atmosphere by $\mathrm{N}_{2}$ may thus have potential as a control measure to prevent outgrowth of Pseudomonas spp. during cold storage of raw milk. However, information in the literature about the ability of facultative anaerobic species of the genus Bacillus and its allied genera and of the facultative anaerobic genus Serratia to produce extracellular enzymes under anaerobic conditions is lacking at this time. Furthermore, practical applications must be evaluated at dairy farm and industrial level. $\mathrm{CO}_{2}$ treatment of raw milk has also been shown to reduce the microbial growth in raw milk (Ma et al., 2003; Vianna et al., 2012; Lo et al., 2016). Lo et al. (2016) observed that in $\mathrm{CO}_{2}$-treated raw milk samples a clear inhibition of bacterial growth compared to non-treated samples, resulting in a delay of spoilage by at least seven days. Using NGS, a relatively lower number of Pseudomonas and Serratia reads were found in three out of five $\mathrm{CO}_{2}$-treated raw milk samples, indicating selective growth inhibition of these genera. However, a disadvantage of $\mathrm{CO}_{2}$ treatment is that it reduces the $\mathrm{pH}$ of the milk (Ma et al., 2003) which may result in changes of (heat)stability.

A third and probably the most cost-effective option for control of spoilage caused by heat-resistant bacterial enzyme activity is hygiene: preventing the contamination of raw milk with psychrotrophic bacteria. Good hygiene practices during milking, cold-storage and transport of the raw milk may reduce the risk of contamination, as these bacteria mainly originate from the udder, milking equipment and milk storage tanks. Wash water used to clean milking equipment has also been shown to be an important source of Pseudomonas contamination of raw milk, indicating the need for attention to water quality (Perkins et al., 2009; Leriche and Fayolle, 2012). Specific pre-milking teat cleaning strategies have been shown to reduce the spore count in milk by $>1 \log$ (Magnusson et al., 2006). It remains to be investigated whether such udder hygiene management strategies are also effective to reduce the psychrotrophic non-spore forming count in view of the study of Mallet et al. (2012) which showed that teat care has more influence on the composition of technologically relevant microbial groups than on the composition of other groups such as Pseudomonas and other Gram-negative bacteria. This may indicate that control of biofilms in milk production and processing environments is maybe more important (reviewed by Marchand et al., 2012; Aswathanarayan and Vittal, 2014; Nucera et al., 2016), as release of vegetative cells or spoilage enzymes from these biofilms may compromise the quality of UHT products (Flach et al., 2014; Teh et al., 2014b). Prevention of biofilm formation may possibly be achieved by specific coating of stainless steel surfaces of milk equipment and milk storing tanks with spoilage bacteria, as was recently shown for milk spore-formers on plate heat exchanger surfaces (Jindal et al., 2016). Biofilms are difficult to remove because the bacteria are protected from disinfectants due to the presence of extracellular polymeric substances. The hygienic design of milking and milk storage equipment as well as effective cleaning and disinfection procedures and proper application are all important factors in the control of biofilms in the dairy industry (Marchand et al., 2012). To remove bacterial biofilms on stainless steel surfaces, the use of specific disinfecting agents, such as products based on hydrogen peroxide and peroxyacetic acid, as well as higher concentrations and longer contact times may be required (Królasik et al., 2010).

Recently, some novel strategies based on the reduction of the bacterial contamination of the raw milk have been proposed as potential measures to extend the shelf life of UHT products, such as the use of microfiltration and the application of lytic bacteriophages. Microfiltration ( $1.4 \mu \mathrm{m}$ pore diameter) resulted in 1-2 log reduction of the psychrotrophic bacterial count of the raw milk and ESL by 21 to 63 days of the UHT-treated milk for low and high somatic cell count (SCC) raw milk, respectively (Zhang et al., 2016). The practical application of microfiltration at the farm is questionable, however, since the cream must be removed from the raw milk before such treatment is possible. Application of a lytic phage cocktail against Pseudomonas was shown to result in a 1-log reduction of the psychotrophic bacteria of raw milk after 5 days at $4^{\circ} \mathrm{C}$ (Hu et al., 2016). However, the rather limited effect and the fact that the use of bacteriophages in food is strictly regulated in many countries will probably hamper practical application.

\section{CONCLUSION}

The combination of psychrotrophic growth in cooled raw milk with the concomitant production of heat-resistant spoilage enzymes presents a formidable challenge to the dairy industry, which relies on refrigerated storage of the raw milk supply and high temperature treatment to produce long shelf life products like UHT-milk and other related dairy products and milk powder. The predominant genus responsible for milk spoilage worldwide found in cold raw milk is Pseudomonas, although in specific regions Serratia is considered a predominant genus responsible for milk spoilage appearing in cold raw milk. Further research using cultivation-independent metagenomics studies should be performed to exclude possible cultivation biases in most of the studies performed up to now. But bacterial isolates will remain necessary to establish whether they truly produce heat resistant enzymes relevant for spoilage of UHT-milk and related products. The current scientific knowledge on peptidase and lipase enzyme production and activity in these microorganisms still gives no viable possible control options. At present, these microorganisms should be controlled as much as possible at each step of the dairy production chain taking into account an optimal hygiene and cooling management. However, a taxonomically exact and region tailored knowledge of the heat-resistant spoilage enzyme producing microbiota in raw milk will help to trace the contamination sources in the supply and production chain in order to prevent their entrance. The data on the microbiota composition in raw milk presented in this review on a worldwide scale may offer the necessary points of view to look for specific as well as common patterns of contamination with these spoilage microorganisms. On the other hand, a first fast screening at the dairy processing plant of the incoming raw milk for potential 
heat-resistant spoilage enzymatic activity would be helpful to steer the milk flow toward processing for long shelf life milk products such as UHT-milk or toward other shorter shelf life products. No such test, which would require very high sensitivity, is currently available; its development represents an enormous scientific challenge.

\section{AUTHOR CONTRIBUTIONS}

SGM, FB, MH, and MV contributed substantially to the conception of this review. SM, JD, and $\mathrm{MH}$ have participated

\section{REFERENCES}

Adams, D. M., and Brawley, T. G. (1981). Heat resistant bacterial lipases and ultrahigh temperature sterilization of dairy products. J. Dairy Sci. 64, 1951-1957. doi: $10.3168 /$ jds.S0022-0302(81)82796-8

Ahn, J. H., Pan, J. G., and Rhee, J. S. (1999). Identification of the tliDEF ABC transporter specific for lipase in Pseudomonas fluorescens SIK W1. J. Bacteriol. $181,1847-1852$.

Andersson, R. E. (1980). Microbial lipolysis at low temperatures. Appl. Environ. Microbiol. 39, 36-40.

Andersson, R. E., Hedlund, C. B., and Jonsson, U. (1979). Thermal inactivation of a heat-resistant lipase produced by the psychotrophic bacterium Pseudomonas fluorescens. J. Dairy Sci. 62, 361-367. doi: 10.3168/jds.S0022-0302(79)83252-X

Anthonsen, H. W., Baptista, A., Drablos, F., Martel, P., Petersen, S. B., Sebastiao, M., et al. (1995). Lipases and esterases: a review of their sequences, structure and evolution. Biotechnol. Annu. Rev. 1,315-371. doi: 10.1016/S13872656(08)70056-5

Arcuri, E. F., Silva, P., Brito, M., Brito, J. R. F., Lange, C. C., and Magalhães, M. (2008). Contagem, isolamento e caracterização de bactérias psicrotróficas contaminantes de leite cru refrigerado. Cienc. Rural 38, 2250-2255. doi: 10. 1590/S0103-84782008000800025

Arpigny, J. L., and Jaeger, K. E. (1999). Bacterial lipolytic enzymes: classification and properties. Biochem. J. 343, 177-183. doi: 10.1042/bj3430177

Aswathanarayan, J. B., and Vittal, R. R. (2014). Attachment and biofilm formation of Pseudomonas fluorescens PSD4 isolated from a dairy processing line. Food Sci. Biotechnol. 23, 1903-1910. doi: 10.1007/s10068-014-0260-8

Azcona, J. I., Martin, R., Hernandez, P. E., and Sanz, B. (1989). Partial immunological characterization of heat-stable proteinases from Pseudomonas spp. of dairy origin. J. Appl. Bacteriol. 66, 227-233. doi: 10.1111/j.1365-2672. 1989.tb02473.x

Baglinière, F., Matéos, A., Tanguy, G., Jardin, J., Briard-Bion, V., Rousseau, F., et al. (2013). Proteolysis of ultra-high temperature-treated casein micelles by AprX enzyme from Pseudomonas fluorescens $\mathrm{F}$ induces their destabilisation. Int. Dairy J. 31, 55-61. doi: 10.1016/j.idairyj.2013.02.011

Baglinière, F., Tanguy, G., Jardin, J., Matéos, A., Briard, V., Rousseau, F., et al. (2012). Quantitative and qualitative variability of the caseinolytic potential of different strains of Pseudomonas fluorescens: implications for the stability of casein micelles of UHT milks during their storage. Food Chem. 135, 2593-2603. doi: 10.1016/j.foodchem.2012.06.099

Bai, A., and Rai, V. R. (2011). Bacterial quorum sensing and food industry. Compr. Rev. Food Sci. Food Saf. 10, 183-193. doi: 10.1111/j.1541-4337.2011.00150.x

Barrett, A. J. (2001). "Proteolytic Enzymes: nomemclature and classification," in Proteolytic Enzymes: A Pratical Approach, 2nd Edn, eds R. Beynon and J. S. Bond (Oxford: Oxford University Press), 1-21.

Baur, C., Krewinkel, M., Kranz, B., von Neubeck, M., Wenning, M., Scherer, S., et al. (2015a). Quantification of the proteolytic and lipolytic activity of microorganisms isolated from raw milk. Int. Dairy J. 49, 23-29. doi: 10.1016/ j.idairyj.2015.04.005

Baur, C., Krewinkel, M., Kutzli, I., Kranz, B., von Neubeck, M., Huptas, C., et al. (2015b). Isolation and characterisation of a heat-resistant peptidase from Pseudomonas panacis withstanding general UHT processes. Int. Dairy J. 49, 46-55. doi: 10.1016/j.idairyj.2015.04.009 in the acquisition of data about the relationship between offflavors and proteolysis in milk samples. EV contributed to the section on control of spoilage by heat-resistant bacterial enzymes. MV, EV, and JD also provided a critical review of the manuscript.

\section{ACKNOWLEDGMENTS}

The authors would like to thank CAPES and CNPq. We acknowledge Springer as original publisher of Figure 3 in this review.

Bekker, A., Jooste, P., Steyn, L., Bothma, C., and Hugo, A. (2016). Lipid breakdown and sensory analysis of milk inoculated with Chryseobacterium joostei or Pseudomonas fluorescens. Int. Dairy J. 52, 101-106. doi: 10.1016/j.idairyj.2015. 09.003

Bekker, A., Steyn, L., Charimba, G., Jooste, P., and Hugo, C. (2015). Comparison of the growth kinetics and proteolytic activities of Chryseobacterium species and Pseudomonas fluorescens. Can. J. Microbiol. 61, 977-982. doi: 10.1139/cjm2015-0236

Belloque, J., Carrascosa, A. V., and Lopez-Fandino, R. (2001). Changes in phosphoglyceride composition during storage of ultrahigh-temperature milk, as assessed by 31P-nuclear magnetic resonance: possible involvement of thermoresistant microbial enzymes. J. Food Prot. 64, 850-855. doi: 10.4315/ 0362-028X-64.6.850

Bertazzoni Minelli, E., Benini, A., Marzotto, M., Sbarbati, A., Ruzzenente, O., Ferrario, R., et al. (2004). Assessment of novel probiotic Lactobacillus casei strains for the production of functional dairy foods. Int. Dairy J. 14, 723-736. doi: 10.1016/j.idairyj.2004.01.007

Beven, C. A., Dieckelmann, M., and Beacham, I. R. (2001). A strain of Pseudomonas fluorescens with two lipase-encoding genes, one of which possibly encodes cytoplasmic lipolytic activity. J. Appl. Microbiol. 90, 979-987. doi: 10.1046/j. 1365-2672.2001.01333.x

Boari, C. A., Alves, M. P., Tebaldi, V. M. R., Savian, T. V., and Piccoli, R. H. (2009). Formação de biofilme em aço inoxidável por Aeromonas hydrophila e Staphylococcus aureus usando leite e diferentes condições de cultivo. Ciênc. Tecnol. Aliment. 29, 886-895. doi: 10.1590/S0101-20612009000400029

Boubendir, A., Serrazanetti, D. I., Hamidechi, M. A., Vannini, L., and Guerzoni, M. E. (2016). Changes in bacterial populations in refrigerated raw milk collected from a semi-arid area of Algeria. Ann. Microbiol. 66, 777-783. doi: 10.1007/ s13213-015-1163-5

Bourlieu, C., Rousseau, F., Briard-Bion, V., Madec, M.-N., and Bouhallab, S. (2012). Hydrolysis of native milk fat globules by microbial lipases: mechanisms and modulation of interfacial quality. Food Res. Int. 49, 533-544. doi: 10.1016/j. foodres.2012.07.036

Braem, G., De Vliegher, S., Verbist, B., Heyndrickx, M., Leroy, F., and De Vuyst, L. (2012). Culture-independent exploration of the teat apex microbiota of dairy cows reveals a wide bacterial species diversity. Vet. Microbiol. 157, 383-390. doi: 10.1016/j.vetmic.2011.12.031

Burger, M., Woods, R. G., McCarthy, C., and Beacham, I. R. (2000). Temperature regulation of peptidase in Pseudomonas fluorescens LS107d2 by an ECF sigma factor and a transmembrane activator. Microbiology 146, 3149-3155. doi: 10 . 1099/00221287-146-12-3149

Cais-Sokolinska, D., and Pikul, J. (2008). Evaluation of steel surface cleanliness level in dairies using the bioluminescence method. Bull. Vet. Inst. Pulawy 52, 625-629.

Caldera, L., Franzetti, L., Van Coillie, E., De Vos, P., Stragier, P., De Block, J., et al. (2016). Identification, enzymatic spoilage characterization and proteolytic activity quantification of Pseudomonas spp. isolated from different foods. Food Microbiol. 54, 142-153. doi: 10.1016/j.fm.2015. 10.004

Cardoso, R. R. (2006). Influência da Microbiota Psicrotrófica no Rendimento de Queijo Minas Frescal Elaborado com Leite Estocado sob Refrigeração. Master's thesis. Federal University of Viçosa, Viçosa. 
Catanio, F. S., Inay, O. M., Silva, A. S., Pereira, J. R., Tamanini, R., Beloti, V., et al. (2012). Refrigerated raw milk quality of a processing plant in the north of Parana after the implementation of changes imposed by NI 62 of 2011. Semina 33, 3171-3180. doi: 10.5433/1679-0359.2012v33supl2p3171

Celestino, E. L., Iyer, M., and Roginski, H. (1997). Reconstituted UHT-treated milk: effects of raw milk, powder quality and storage conditions of UHT milk on its physico-chemical attributes and flavour. Int. Dairy J. 7, 129-140. doi: 10.1016/S0958-6946(96)00042-8

Chabeaud, P., De Groot, A., Bitter, W., Tommassen, J., Heulin, T., and Achouack, W. (2001). Phase variable expression of an operon encoding extracellular alkaline protease, a serine protease homolog, and lipase in Pseudomonas brassicacearum. J. Bacteriol. 183, 2117-2120. doi: 10.1128/JB.183. 6.2117-2120.2001

Chen, L., Coolbear, T., and Daniel, R. M. (2004). Characteristics of proteinases and lipases produced by seven Bacillus sp. isolated from milk powder production lines. Int. Dairy J. 14, 495-504. doi: 10.1016/j.idairyj.2003.10.006

Chen, L., Daniel, R. M., and Coolbear, T. (2003). Detection and impact of peptidase and lipase activities in milk and milk powders. Int. Dairy J. 13, 255-275. doi: 10.1016/S0958-6946(02)00171-1

Chen, T. R., Wei, Q. K., and Chen, Y. J. (2011). Pseudomonas spp. and Hafnia alvei growth in UHT milk at cold storage. Food Control 22, 697-701. doi: 10.1016/j.foodcont.2010.10.004

Chopra, A. K., and Mathur, D. K. (1984). Isolation, screening and characterization of thermophilic Bacillus species isolated from dairy products. J. Appl. Bacteriol. 57, 263-271. doi: 10.1111/j.1365-2672.1984.tb01390.x

Chopra, A. K., and Mathur, D. K. (1985). Purification and characterization of heat-stable peptidases from Bacillus stearothermophilus RM-67. J. Dairy Sci. 68, 3202-3211. doi: 10.3168/jds.S0022-0302(85)81228-5

Christensen, A. B., Riedel, K., Eberl, L., Flodgaard, L. R., Molin, S., Gram, L., et al. (2003). Quorum-sensing-directed protein expression in Serratia proteamaculans B5a. Microbiology 149, 471-483. doi: 10.1099/mic.0.25575-0

Cleto, S., Matos, S., Kluskens, L., and Vieira, M. J. (2012). Characterization of contaminants from a sanitized milk processing plant. PLoS ONE 7:e40189. doi: 10.1371/journal.pone.0040189

Coorevits, A., De Jonghe, V., Vandroemme, J., Van Landschoot, A., Heyndrickx, M., and De Vos, P. (2010). "How can the type of dairy farming influence the bacterial flora in milk?", in Organic Farming and Peanut Crops, eds D. C. Grossman and T. L. Barrios (Ghent: Nova Science Publishers, Inc.), 123-136.

Costa, L. M., Gómez, F. S., Molina, L. H. C., Simpson, R. R., and Romero, A. M. (2002). Purificación y caracterización de proteasas de Pseudomonas fluorescens y sus efectos sobre las proteínas de la leche. Arch. Latinoam. Nutr. 52, 1-13.

Craven, H. M., and Macauley, B. J. (1992). Microorganisms in pasteurised milkafter refrigerated storage 1. Identification of types. Aust. J. Dairy Technol. 47, 38-45.

Darchuk, E. M., Waite-Cusic, J., and Meunier-Goddik, L. (2015). Effect of commercial hauling practices and tanker cleaning treatments on raw milk microbiological quality. J. Dairy Sci. 98, 7384-7393. doi: 10.3168/jds. 2015-9746

Datta, N., and Deeth, H. C. (2001). Age gelation of UHT milk-a review. Food Bioprod. Process. 79, 197-210. doi: 10.1205/096030801753252261

Datta, N., and Deeth, H. C. (2003). Diagnosing the cause of proteolysis in UHT milk. LWT Food Sci. Technol. 36, 173-182. doi: 10.1016/S0023-6438(02) 00214-1

De Jonghe, V., Coorevits, A., De Block, J., Van Coillie, E., Grijspeerdt, K., Herman, L., et al. (2010). Toxinogenic and spoilage potential of aerobic sporeformers isolated from raw milk. Int. J. Food Microbiol. 136, 318-325. doi: 10.1016/j.ijfoodmicro.2009.11.007

De Jonghe, V., Coorevits, A., Van Hoorde, K., Messens, W., Landshoot, A., De Vos, P., et al. (2011). Influence of storage conditions on the growth of Pseudomonas species in refrigerated raw milk. Appl. Environ. Microbiol. 77, 460-470. doi: 10.1128/AEM.00521-10

De Oliveira, G. B., Favarin, L., Luchese, R. H., and McIntosh, D. (2015). Psychrotrophic bacteria in milk: how much do we really know? Braz. J. Microbiol. 46, 313-321. doi: 10.1590/S1517-838246220130963

Decimo, M., Brasca, M., Ordóñez, J. A., and Cabeza, M. C. (2016). Fatty acids released from cream by psychrotrophs isolated from bovine raw milk. Int. J. Dairy Technol. 69, 1-6. doi: 10.1111/1471-0307.12347
Decimo, M., Morandi, S., Silvetti, T., and Brasca, M. (2014). Characterization of gram-negative psychrotrophic bacteria isolated from Italian bulk tank milk. J. Food Sci. 79, M2081-M2090. doi: 10.1111/1750-3841.12645

Deeth, H. C. (2006). Lipoprotein lipase and lipolysis in milk. Int. Dairy J. 16, 555-562. doi: 10.1016/j.idairyj.2005.08.011

Deeth, H. C. (2011). "Lipolysis and hydrolytic rancidity," in Encyclopedia of Dairy Sciences, 2nd Edn, Vol. 3, eds J. W. Fuquay, P. F. Fox, and P. L. H. McSweeney (Oxford: Academic Press), 721-726. doi: 10.1016/B978-0-12-374407-4. 00343-5

Delbès, C., Ali-Mandjee, L., and Montel, M.-C. (2007). Monitoring bacterial communities in raw milk and cheese by culture-dependent and -independent 16S rRNA gene-based analyses. Appl. Environ. Microbiol. 73, 1882-1891. doi: 10.1128/AEM.01716-06

Demidyuk, I. V., Kalashnikov, A. E., Gromova, T. Y., Gasanov, E. V., Safina, D. R., Zabolotskaya, M. V., et al. (2006). Cloning, sequencing, expression, and characterization of protealysin, a novel neutral proteinase from Serratia proteamaculans representing a new group of thermolysin-like peptidases with short N-terminal region of precursor. Protein Expr. Purif. 47, 551-561. doi: 10.1016/j.pep.2005.12.005

Desmasures, N., Bazin, F., and Gueguen, M. (1997a). Microbiological composition of raw milk from selected farms in the Camembert region of Normandy. J. Appl. Microbiol. 83, 53-58. doi: 10.1046/j.1365-2672.1997.00166.x

Desmasures, N., Opportune, W., and Gueguen, M. (1997b). Lactococcus spp., yeasts, and Pseudomonas spp. on teats and udders of milking cows as potential sources of milk contamination. Int. Dairy J. 7, 643-646. doi: 10.1016/S09586946(97)00042-3

Dogan, B., and Boor, K. J. (2003). Genetic diversity and spoilage potentials among Pseudomonas spp. isolated from fluid milk products and dairy processing plants. Appl. Environ. Microbiol. 69, 130-138. doi: 10.1128/AEM.69.1.130-138. 2003

Dufour, D., Nicodème, M., Perrin, C., Driou, A., Brusseaux, E., Humbert, G., et al. (2008). Molecular typing of industrial strains of Pseudomonas spp. isolated from milk and genetical and biochemical characterization of an extracellular peptidase produced by one of them. Int. J. Food Microbiol. 125, 188-196. doi: 10.1016/j.ijfoodmicro.2008.04.004

Elmoslemany, A. M., Keefe, G. P., Dohoo, I. R., Wichtel, J. J., Stryhn, H., and Dingwell, R. T. (2010). The association between bulk tank milk analysis for raw milk quality and on-farm management practices. Prev. Vet. Med. 95, 32-40. doi: 10.1016/j.prevetmed.2010.03.007

Eom, G. T., Oh, J. Y., and Song, J. K. (2014). High-level production of Serratia proteamaculans metallopeptidase using a recombinant $\mathrm{ABC}$ protein exportermediated secretion system in Pseudomonas fluorescens. Process. Biochem. 49, 1718-1722. doi: 10.1016/j.procbio.2014.06.006

Ertan, H., Cassel, C., Verma, A., Poljak, A., Charlton, T., Aldrich-Wright, J., et al. (2015). A new broad specificity alkaline metalloprotease from a Pseudomonas sp. isolated from refrigerated milk: role of calcium in improving enzyme productivity. J. Mol. Catal. B Enzym. 113, 1-8. doi: 10.1016/j.molcatb.2014. 12.010

Fairbairn, D. J., and Law, B. A. (1986). Proteinase of psychrotrophic bacteria: their production, properties, effects and control. J. Dairy Res. 53, 139-177. doi: 10.1017/S0022029900024742

Fitz-Gerald, C. H., Deeth, H. C., and Coghill, D. M. (1982). Low temperature inactivation of lipases from psychrotrophic bacteria. Aust. J. Dairy Technol. 37, 459-468.

Flach, J., Grzybowski, V., Toniazzo, G., and Corção, G. (2014). Adhesion and production of degrading enzymes by bacteria isolated from biofilms in raw milk cooling tanks. Food Sci. Technol. 34, 571-576. doi: 10.1590/1678-457X.6374

Fox, P. F., and Stepaniak, L. (1983). Isolation and some properties of extracellular heat-stable lipases from Pseudomonas fluorescens strain AFT 36. J. Dairy Res. 50, 77-89. doi: 10.1017/S0022029900032544

Fuqua, W. C., Winans, S. C., and Greenberg, E. P. (1994). Quorum sensing in bacteria: the LuxR-LuxI family of cell density-responsive transcriptional regulators. J. Bacteriol. 176, 269-275. doi: 10.1128/jb.176.2.269-275.1994

Garcia Barbero, V. (1998). Calidad higiénica de la leche: causas y prevención de la contaminación bacteriana de la leche. Bovis 85, 45-71.

Gaucher, I., Tanguy, G., Fauquant, J., Jardin, J., Rousseau, F., Robert, B., et al. (2011). Proteolysis of casein micelles by Pseudomonas fluorescens CNRZ 798 
contributes to the destabilisation of UHT milk during its storage. Dairy Sci. Technol. 91, 413-429. doi: 10.1007/s13594-011-0019-4

Giannino, M. L., Marzotto, M., Dellaglio, F., and Feligini, M. (2009). Study of microbial diversity in raw milk and fresh curd used for Fontina cheese production by culture-independent methods. Int. J. Food Microbiol. 130, 188-195. doi: 10.1016/j.ijfoodmicro.2009.01.022

Givskov, M., Eberl, L., and Molin, S. (1997). Control of exoenzyme production, motility and cell differentiation in Serratia liquefaciens. FEMS Microbiol. Lett. 148, 115-122. doi: 10.1111/j.1574-6968.1997.tb10276.x

Glück, C., Rentschler, E., Krewinkel, M., Merz, M., von Neubeck, M., Wenning, M., et al. (2016). Thermostability of peptidases secreted by microorganisms associated with raw milk. Int. Dairy J. 56, 186-197. doi: 10.1016/j.idairyj.2016. 01.025

Gopal, N., Hill, C., Ross, P. R., Beresford, T. P., Fenelon, M. A., and Cotter, P. D. (2015). The prevalence and control of Bacillus and related spore-forming bacteria in the dairy industry. Front. Microbiol. 6:1418. doi: 10.3389/fmicb.2015. 01418

Gschwendtner, S., Alatossava, T., Kublik, S., Fuka, M. M., Schloter, M., and Munsch-Alatossava, P. (2016). N2 gas flushing alleviates the loss of bacterial diversity and inhibits psychrotrophic Pseudomonas during the cold storage of bovine raw milk. PLoS ONE 11:e0146015. doi: 10.1371/journal.pone.0146015

Hagiya, H., Ojima, M., Yoshida, T., Matsui, T., Morii, E., Sato, K., et al. (2016). Necrotizing soft tissue infection caused by Serratia marcescens: a case report and literature review. J. Infect. Chemother. 22, 335-338. doi: 10.1016/j.jiac.2015. 11.013

Hamada, K., Hata, Y., Katsuya, Y., Hiramatsu, H., Fujiwara, T., and Katsube, Y. (1996). Crystal structure of Serratia peptidase, a zinc-dependent proteinase from Serratia sp. E-15, containing a $\beta$-sheet coil motif at 2.0 A $\AA$ resolution. $J$ Biochem. 119, 844-851. doi: 10.1093/oxfordjournals.jbchem.a021320

Hanamant, P. S., and Bansilal, G. M. (2012). Proteolytic psychrotrophic Bacillus cereus from milk and fermented milk products. J. Environ. Res. Dev. 6, 660-666.

Hanamant, P. S., and Bansilal, G. M. (2013). Lipolytic psychrotrophic grampositive cocci in milk and fermented milk products. J. Environ. Res. Dev. 8, 273-279.

Hantis-Zacharov, E., and Halpern, M. (2007). Culturable psychrotrophic bacterial communities in raw milk and their proteolytic and lipolytic traits. Appl. Environ. Microbiol. 73, 7162-7168. doi: 10.1128/AEM.00866-07

Hasan, F., Shah, A. A., and Hameed, A. (2006). Industrial applications of microbial lipases. Enzyme Microb. Technol. 39, 235-251. doi: 10.1016/j.enzmictec.2005. 10.016

Hu, Z., Meng, X.-C., and Liu, F. (2016). Isolation and characterisation of lytic bacteriophages against Pseudomonas spp., a novel biological intervention for preventing spoilage of raw milk. Int. Dairy J. 55, 72-78. doi: 10.1016/j.idairyj. 2015.11.011

Ishii, K., Adachi, T., Hara, T., Hamamoto, H., and Sekimizu, K. (2014). Identification of a Serratia marcescens virulence factor that promotes hemolymph bleeding in the silkworm, Bombyx mori. J. Inverteb. Pathol. 117, 61-67. doi: 10.1016/j.jip.2014.02.001

Jaeger, K. E., Dijkstra, B. W., and Reetz, M. T. (1999). Bacterial biocatalysts: molecular biology, three-dimensional structures, and biotechnological applications of lipases. Annu. Rev. Microbiol. 53, 315-351. doi: 10.1146/annurev.micro.53.1.315

Jaeger, K. E., Ransac, S., Dijkstra, B. W., Colson, C., van Heuvel, M., and Misset, O. (1994). Bacterial lipases. FEMS Microbiol. Rev. 15, 29-63. doi: 10.1111/j.15746976.1994.tb00121.x

Jayarao, B. M., and Wang, L. (1999). A study on the prevalence of gram-negative bacteria in bulk tank milk. J. Dairy Sci. 82, 2620-2624. doi: 10.3168/jds.S00220302(99)75518-9

Jayaratne, P. (1996). Major metallopeptidase gene of Serratia marcescens is conserved and provides a molecular typing method to differentiate clinical isolates. J. Microbiol. Methods 26, 261-269. doi: 10.1016/0167-7012(96)00922-0

Jindal, S., Anand, S., Huang, K., Goddard, J., Metzger, L., and Amamcharla, J. (2016). Evaluation of modified stainless steel surfaces targeted to reduce biofilm formation by common milk sporeformers. J. Dairy Sci. 99, 1-12. doi: 10.3168/ jds.2016-11395

Jost, L. (2007). Partitioning diversity into independent alpha and beta components. Ecology 88, 2427-2439. doi: 10.1890/06-1736.1
Juhas, M., Eberl, L., and Tümmler, B. (2005). Quroum sensing: the power of cooperation in the world of Pseudomonas. Environ. Microbiol. 7, 459-471. doi: 10.1111/j.1462-2920.2005.00769.x

Kable, M. E., Srisengfa, Y., Laird, M., Zaragoza, J., McLeod, J., Heidenreich, J., et al. (2016). The core and seasonal microbiota of raw bovine milk in tanker trucks and the impact of transfer to a milk processing facility. MBio 7:e00836-16. doi: $10.1128 / \mathrm{mBio} .00836-16$

Kaibara, F., Iiyama, K., Chieda, Y., Man Lee, J., Kusakabe, T., Yasunaga-Aoki, C., et al. (2012). Construction of serralysin-like metallopeptidase-deficient mutants of Serratia liquefaciens and their virulence in the silkworm, Bombyx mori. J. Insect. Biotechnol. Sericol. 81, 55-61. doi: 10.11416/jibs.81.2_3_055

Kaibara, F., Iiyama, K., Yasunaga-Aoki, C., and Shimizu, S. (2010). Molecular cloning of serralysin-like melallopeptidase ser1 gene from Serratia liquefaciens. Entomotech 34, 25-27.

Kessler, H. G. (ed.). (1996). "Wärmtebehandlung und effecte - sterilprozesstechnik - proteindenaturierung and -strukturierung," in Lebensmittel- und Bioverfahrenstechnik - Molkereitechnologie (Freising: A. Kessler), 127-216.

Kim, H., Hardy, J., Novak, G., Ramet, J. P., and Weber, F. (1983). Off-Tastes in Raw and Reconstituted Milk, FAO Animal Production and Health Paper 35, Vol. 35. Rome: Food \& Agriculture Organization of the United Nations, 2.

Kim, H.-J., Tamanoue, Y., Jeohn, G.-H., Iwamatsu, A., Yokota, A., Kim, Y.-T., et al. (1997). Purification and characterization of an extracellular metallopeptidase from Pseudomonas fluorescens. J. Biochem. 121, 82-88. doi: 10.1093/oxfordjournals.jbchem.a021575

Kim, H. K., Park, S. Y., Lee, J. K., and Oh, T. K. (1998). Gene cloning and characterization of thermostable lipase from Bacillus stearothermophilus L1. Biosci. Biotechnol. Biochem. 62, 66-71. doi: 10.1271/bbb.62.66

Kohlmann, K. L., Nielsen, S. S., and Ladisch, M. R. (1991). Purification and characterization of an extracellular peptidase produced by Pseudomonas fluorescens M3/6. J. Dairy Sci. 74, 4125-4136. doi: 10.3168/jds.S0022-0302(91) 78607-4

Kramer, A. (1960). A rapid method for determining significance of differences from rank sums. Food Technol. 14, 576-581.

Królasik, J., Zakowska, Z., Krepska, M., and Klimek, L. (2010). Resistance of bacterial biofilms formed on stainless steel surface to disinfecting agent. Pol. J. Microbiol. 59, 281-287.

Kumeta, H., Hoshino, T., Goda, T., Okayama, T., Shimada, T., Ohgiya, S., et al. (1999). Identification of a member of the serralysin family isolated from a psychrotrophic bacterium, Pseudomonas fluorescens 114. Biosci. Biotechnol. Biochem. 63, 1165-1170. doi: 10.1271/bbb.63.1165

Kumura, H., Mikawa, K., and Saito, Z. (1993a). Influence of milk proteins on the thermostability of the lipase from Pseudomonas fluorescens 33. J. Dairy Sci. 76, 2164-2167. doi: 10.3168/jds.S0022-0302(93)77552-9

Kumura, H., Mikawa, K., and Saito, Z. (1993b). Purification and some properties of proteinase from Pseudomonas fluorescens No. 33. J. Dairy Res. 60, 229-237.

Lafarge, V., Ogier, J.-C., Girard, V., Maladen, V., Leveau, J.-Y., Gruss, A., et al. (2004). Raw cow milk bacterial population shifts attributable to refrigeration. Appl. Environ. Microbiol. 70, 5644-5650. doi: 10.1128/AEM.70.9.5644-5650. 2004

Law, B. A., Sharpe, M. E., and Chapman, H. R. (1976). The effect of lipolytic Gram-negative psychrotrophs in stored milkon the development of rancidity in Cheddar cheese. J. Dairy Res. 43, 459-468. doi: 10.1017/S0022029900016046

Leriche, F., and Fayolle, K. (2012). No seasonal effect on culturable pseudomonads in fresh milks from cattle herds. J. Dairy Sci. 95, 2299-2306. doi: 10.3168/jds. 2011-4785

Letoffe, S., Delepelaire, P., and Wandersman, C. (1991). Cloning and expression in Escherichia coli of the Serratia marcescens metallopeptidase gene: secretion of the peptidase from E. coli in the presence of the Erwinia chrysanthemi peptidase secretion functions. J. Bacteriol. 173, 2160-2166. doi: 10.1128/jb.173.7.21602166.1991

Liao, C.-H., and McCallus, D. E. (1998). Biochemical and genetic characterization of an extracellular peptidase from Pseudomonas fluorescens CY091. Appl. Environ. Microbiol. 64, 914-921.

Liu, K., Tang, Y.-Q., Matsui, T., Morimura, S., Wu, X.-L., and Kida, K. (2009). Thermophilic anaerobic co-digestion of garbage, screened swine and dairy cattle manure. J. Biosci. Bioeng. 107, 54-60. doi: 10.1016/j.jbiosc.2008. 09.007 
Liu, M., Wang, H., and Griffiths, M. W. (2007). Regulation of alkaline metallopeptidase promoter by $\mathrm{N}$-acyl homoserine lactone quorum sensing in Pseudomonas fluorescens. J. Appl. Microbiol. 103, 2174-2184. doi: 10.1111/j. 1365-2672.2007.03488.x

Lo, R., Turner, M. S., Weeks, M., and Bansal, N. (2016). Culture-independent bacterial community profiling of carbon dioxide treated raw milk. Int. J. Food Microbiol. 233, 81-89. doi: 10.1016/j.ijfoodmicro.2016.06.015

Ma, Y., Barbano, D. M., and Santos, M. (2003). Effect of CO2 addition to raw milk on proteolysis and lipolysis at $4^{\circ}$ C. J. Dairy Sci. 86, 1616-1631. doi: 10.3168/jds. S0022-0302(03)73747-3

Machado, S. G., Heyndrickx, M., De Block, J., Devreese, B., Vandenberghe, I., Vanetti, M. C. D., et al. (2016). Identification and characterization of a heatresistant peptidase from Serratia liquefaciens isolated from Brazilian cold raw milk. Int. J. Food Microbiol. 222, 65-71. doi: 10.1016/j.ijfoodmicro.2016.01.014

Machado, S. G., Silva, F. L., Bazzolli, D. M. S., Heyndrickx, M., Costa, P. M. A., and Vanetti, M. C. D. (2015). Pseudomonas spp. and Serratia liquefaciens as predominant spoilers in Brazilian cold raw milk. J. Food Sci. 80, M1842-M1849. doi: $10.1111 / 1750-3841.12957$

Magnusson, M., Christiansson, A., Svensson, B., and Kolstrup, C. (2006). Effect of different premilking manual teat-cleaning methods on bacterial spores in milk. J. Dairy Sci. 89, 3866-3875. doi: 10.3168/jds.S0022-0302(06)72429-8

Makhzoum, A., Knapp, J. S., and Owusu, R. K. (1995). Factors affecting growth and extracelluar lipase production by Pseudomonas fluorescens 2D. Food Microbiol. 12, 277-290. doi: 10.1016/S0740-0020(95)80108-1

Malacarne, M., Summer, A., Franceschi, P., Formaggioni, P., Pecorari, M., Panari, G., et al. (2013). Effects of storage conditions on physico-chemical characteristics, salt equilibria, processing properties and microbial development of raw milk. Int. Dairy J. 29, 36-41. doi: 10.1016/j.idairyj.2012.10.005

Mallet, A., Guéguen, M., Kauffmann, F., Chesneau, C., Sesboué, A., and Desmasures, N. (2012). Quantitative and qualitative microbial analysis of raw milk reveals substantial diversity influenced by herd management practices. Int. Dairy J. 27, 13-21. doi: 10.1016/j.idairyj.2012.07.009

Mankai, M., Boulares, M., Ben Moussa, O., Karoui, R., and Hassouna, M. (2012). The effect of refrigerated storage of raw milk on the physicochemical and microbiological quality of Tunisian semihard Gouda-type cheese during ripening. Int. J. Dairy Technol. 65, 250-259. doi: 10.1111/j.1471-0307.2012. 00822.x

Mankai, M., Hassouna, M., and Boudabous, A. (2003). Influence de la durée de réfrigération sur la microflore psychrotrophe, la protéolyse et la composition chimique et minérale du lait cru de collecte tunisien. Ind. Alimentaires Agricoles 120, 12-17.

Marchand, S., De Block, J., De Jonghe, V., Coorevits, A., Heyndrickx, M., and Herman, L. (2012). Biofilm formation in milk production and processing environments; influence on milk quality and safety. Compr. Rev. Food Sci. Food Saf. 11, 133-147. doi: 10.1111/j.1541-4337.2011.00183.x

Marchand, S., Duquenne, B., Heyndrickx, M., Coudijzer, K., and De Block, J. (2017). Destabilization and off-flavors generated by Pseudomonas proteases during or after UHT-processing of milk. Int. J. Food Contam. 4, 2-4. doi: 10.1186/s40550-016-0047-1

Marchand, S., Heylen, K., Messens, W., Coudijzer, K., De Vos, P., Dewettinck, K., et al. (2009a). Seasonal influence on heat-resistant proteolytic capacity of Pseudomonas lundensis and Pseudomonas fragi, predominant milk spoilers isolated from Belgian raw milk samples. Environ. Microbiol. 11, 467-482. doi: 10.1111/j.1462-2920.2008.01785.x

Marchand, S., Vandriesche, G., Coorevits, A., Coudijzer, K., De Jonghe, V., Dewettinck, K., et al. (2009b). Heterogeneity of heat-resistant proteases from milk Pseudomonas species. Int. J. Food Microbiol. 133, 68-77. doi: 10.1016/j. ijfoodmicro.2009.04.027

Martins, M. L., de Araújo, E. F., Mantovani, H. C., Moraes, C. A., and Vanetti, M. C. D. (2005). Detection of the apr gene in proteolytic psychrotrophic bacteria isolated from refrigerated raw milk. Int. J. Food Microbiol. 102, 203-211. doi: 10.1016/j.ijfoodmicro.2004.12.016

Martins, M. L., Pinto, U. M., Riedel, K., and Vanetti, M. C. D. (2015). Milkdeteriorating exoenzymes from Pseudomonas fluorescens 041 isolated from refrigerated raw milk. Braz. J. Microbiol. 46, 207-217. doi: 10.1590/s151738246120130859

Masiello, S. N., Martin, N. H., Watters, R. D., Galton, D. M., Schukken, Y. H., Wiedmann, M., et al. (2014). Identification of dairy farm management practices associated with the presence of psychrotolerant sporeformers in bulk tank milk. J. Dairy Sci. 97, 4083-4096. doi: 10.3168/jds.2014-7938

Matéos, A., Guyard-Nicodème, M., Baglinière, F., Jardin, J., Gaucheron, F., Dary, A., et al. (2015). Proteolysis of milk proteins by AprX, an extracellular peptidase identified in Pseudomonas LBSA1 isolated from bulk raw milk, and implications for the stability of UHT milk. Int. Dairy J. 49, 78-88. doi: 10.1016/ j.idairyj.2015.04.008

Matselis, E., and Roussis, I. G. (1998). Proteinase and lipase production by Pseudomonas fluorescens. Proteolysis and lipolysis in thermized ewe's milk. Food Control 9, 251-259. doi: 10.1016/S0956-7135(98)00010-3

Matsumoto, K., Maeda, H., Takata, K., Kamata, R., and Okamura, H. (1984). Purification and characterization of Four peptidases from a clinical isolate of Serratia marcescens kums 3958. J. Bacteriol. 157, 225-232.

Maunsell, B., Adams, C., and O'Gara, F. (2006). Complex regulation of AprA metallopeptidase in Pseudomonas fluorescens M114: evidence for the involvement of iron, the ECF sigma factor, PbrA and pseudobactin M114 siderophore. Microbiology 152, 29-42. doi: 10.1099/mic.0.28379-0

McCarthy, C. N., Woods, R. G., and Beacham, I. R. (2004). Regulation of the aprX-lipA operon of Pseudomonas fluorescens B52: differential regulation of the proximal and distal genes, encoding peptidase and lipase, by ompR-envZ. FEMS Microbiol. Lett. 241, 243-248. doi: 10.1016/j.femsle.2004.10.027

McKellar, R. C. (ed.) (1989). "Regulation and control of synthesis," in Enzymes of Psychrotrophs in Raw Food, (Boca Raton, FL: CRC Press), 153-171.

Merieau, A., Gugi, B., Guespin-Michel, J. F., and Orange, N. (1993). Temperature regulation of lipase secretion by Pseudomonas fluorescens strain MFO. Appl. Microbiol. Biotechnol. 39, 104-109. doi: 10.1007/BF0016 6857

Michel, V., Hauwuy, A., and Chamba, J.-F. (2001). La flore microbienne de laits crus de vache: diversité et influence des conditions de production. Lait 81, 575-592. doi: 10.1051/lait:2001151

Monsallier, F., Verdier-Metz, I., Agabriel, C., Martin, B., and Montel, M.-C. (2012). Variability of microbial teat skin flora in relation to farming practices and individual dairy cow characteristics. Dairy Sci. Technol. 92, 265-278. doi: 10. 1007/s13594-012-0064-7

Mu, Z., Du, M., and Bai, Y. (2009). Purification and properties of a heat-stable enzyme of Pseudomonas fluorescens Rm12 from raw milk. Eur. Food Res. Technol. 228, 725-734. doi: 10.1007/s00217-008-0983-y

Munsch-Alatossava, P., Ghafar, A., and Alatossava, T. (2013). Potential of nitrogen gas (N2) flushing to extend the shelf life of cold stored pasteurised milk. Int. J. Mol. Sci. 14, 5668-5685. doi: 10.3390/ijms14035668

Murphy, S., and Boor, K. (2000). Trouble-shooting sources and causes of high bacteria counts in raw milk. Dairy Food Environ. Sanit. 20, 606-611.

Nabrdalik, M., Grata, K., and Latała, A. (2010). Proteolytic activity of Bacillus cereus strains. Proc. ECOpole 4, 273-277.

Nam, M. S., Whang, K. S., Choi, S. H., Bae, H. C., Kim, Y. K., and Park, Y. W. (2013). Purification, characterization, and properties of an alkaline peptidase produced by Serratia marcescens S3-R1 inhabiting Korean ginseng rhizosphere. J. Sci. Food Agric. 93, 3876-3882. doi: 10.1002/jsfa.6363

Nicodème, M., Grill, J.-P., Humbert, G., and Gaillard, J.-L. (2005). Extracellular peptidase activity of different Pseudomonas strains: dependence of proteolytic activity on culture conditions. J. Appl. Microbiol. 99, 641-648. doi: 10.1111/j. 1365-2672.2005.02634.x

Nörnberg, M. F. B. L., Friedrich, R. S. C., Weiss, R. D. N., Tondo, E. C., and Brandelli, A. (2010). Proteolytic activity among psychrotrophic bacteria isolated from refrigerated raw milk. Int. J. Dairy Technol. 63, 41-46. doi: 10.1111/j.14710307.2009.00542.x

Nucera, D. M., Lomonaco, S., Morra, P., Ortoffi, M. F., Giaccone, D., and Grassi, M. A. (2016). Dissemination and persistence of Pseudomonas spp. in small-scale dairy farms. Ital. J. Food Saf. 5, 91-94. doi: 10.4081/ijfs.2016. 5652

Perin, L. M., Moraes, P. M., Almeida, M. V., and Nero, L. A. (2012). Intereference of storage temperatures in the development of mesophilic, psychrotrophic, lipolytic and proteolytic microbiota of raw milk. Ciênc. Tecnol. Aliment. 33, 333-342. doi: 10.5433/1679-0359.2012v33n1p333

Perkins, N. R., Kelton, D. F., Hand, K. J., MacNaughton, G., Berke, O., and Leslie, K. E. (2009). An analysis of the relationship between bulk tank milk quality and wash water quality on dairy farms in Ontario, Canada. J. Dairy Sci. 92, 3714-3722. doi: $10.3168 /$ jds.2009-2030 
Pinto, A. D., Forte, V., Guastadisegni, M. C., Martino, C., Schena, F. P., and Tantillo, G. (2007). A comparison of DNA extraction methods for food analysis. Food Control 18, 76-80. doi: 10.1016/j.foodcont.2005.08.011

Pinto, C. L. O., Machado, S. G., Cardoso, R. R., Alves, R. M., and Vanetti, M. C. D. (2014). Proteolytic potential of Pseudomonas fluorescens isolated from refrigerated raw milk. Rev. Bras. Agropecu. Sust. 4, 16-25. doi: 10.1590/S1517838246120130859

Pinto, C. L. O., Machado, S. G., Martins, M. L., and Vanetti, M. C. D. (2015). Identificação de bactérias psicrotróficas proteolíticas isoladas de leite cru refrigerado e caracterização de seu potencial deteriorador. Rev. Inst. Laticinios Cândido Tostes 70, 105-116. doi: 10.14295/2238-6416.v70i2.401

Pinto, U. M., Costa, E. D., Mantovani, H. C., and Vanetti, M. C. D. (2010). The proteolytic activity of Pseudomonas fluorescens 07A isolated from milk is not regulated by quorum sensing signals. Braz. J. Microbiol. 41, 91-96. doi: 10.1590/ S1517-838220100001000015

Polychroniadou, A. (1988). A simple procedure using trinitrobenzenesulphonic acid for monitoring proteolysis in cheese. J. Dairy Sci. 55, 585-596. doi: 10.1017/ s0022029900033379

Quigley, L., O'Sullivan, O., Stanton, C., Beresford, T. P., Ross, R. P., Fitzgerald, G. F., et al. (2013). The complex microbiota of raw milk. FEMS Microbiol. Rev. 37, 664-698. doi: 10.1111/1574-6976.12030

Raats, D., Offek, M., Minz, D., and Halpern, M. (2011). Molecular analysis of bacterial communities in raw cow milk and the impact of refrigeration on its structure and dynamics. Food Microbiol. 28, 465-471. doi: 10.1016/j.fm.2010. 10.009

Ranieri, M. L., Ivy, R. A., Mitchell, W. R., Call, E., Masiello, S. N., Wiedmann, M., et al. (2012). Real-Time PCR detection of Paenibacillus spp. in raw milk to predict shelf-life performance of pasteurized fluid milk products. Appl. Environ. Microbiol. 78, 5855-5863. doi: 10.1016/j.fm.2010.10.009

Rasolofo, E. A., LaPointe, G., and Roy, D. (2011). Assessment of the bacterial diversity of treated and untreated milk during cold storage by T-RFLP and PCR-DGGE methods. Dairy Sci. Technol. 91, 573-597. doi: 10.1007/s13594011-0027-4

Rasolofo, E. A., St-Gelais, D., LaPointe, G., and Roy, D. (2010). Molecular analysis of bacterial population structure and dynamics during cold storage of untreated and treated milk. Int. J. Food Microbiol. 138, 108-118. doi: 10.1016/j. ijfoodmicro.2010.01.008

Richard, J., and Houssu, C. (1983). Nature de la flore microbienne dominante et sous-dominante des laits crus très pollués. Lait 63, 148-170. doi: 10.1051/lait: 1983625-62612

Richard, J., Houssu, C., and Braquehaye, C. (1981). Influence de diverses méthodes de nettoyage des machines à traire sur la qualité de conservation du lait cru à basse température. Lait 61, 354-369. doi: 10.1051/lait:198160722

Romero, F. J., García, L. A., Salas, J. A., Díaz, M., and Quirós, L. M. (2001). Production, purification and partial characterization of two extracellular peptidases from Serratia marcescens grown in whey. Process Biochem. 36, 507-515. doi: 10.1016/S0032-9592(00)00221-1

Ryser, E. (1999). Microorganisms of importance in raw milk. Mich. Dairy Rev. 8, 7-9.

Sadiq, F. A., Li, Y., Liu, T., Flint, S., Zhang, G., Yuan, L., et al. (2016). The heat resistance and spoilage potential of aerobic mesophilic and thermophilic spore forming bacteria isolated from Chinese milk powders. Int. J. Food Microbiol. 238, 193-201. doi: 10.1016/j.ijfoodmicro.2016.09.009

Salwan, R., and Kasana, R. C. (2013). Purification and characterization of an extracellular low temperature-active and alkaline stable peptidase from psychrotrophic Acinetobacter sp. MN 12 MTCC (10786). Indian Microbiol. 53, 63-69. doi: 10.1007/s12088-012-0344-1

Samaržija, D., Zamberlin, Š, and Pogačić, T. (2012). Psychrotrophic bacteria and milk and dairy products quality. Mljekarstvo 62, 77-95.

Santos, M. V., Ma, Y., Caplan, Z., and Barbano, D. M. (2003). Sensory threshold of off-flavors caused by proteolysis and lipolysis in milk. J. Dairy Sci. 86, 1601-1607. doi: 10.3168/jds.S0022-0302(03)73745-X

Scheldeman, P., Herman, L., Foster, S., and Heyndrickx, M. (2006). Bacillus sporothermodurans and other highly heat-resistant spore formers in milk. J. Appl. Microbiol. 101, 542-555. doi: 10.1111/j.1365-2672.2006. 02964.x

Schmidt-Dannert, C., Rua, M. L., Atomi, H., and Schmid, R. D. (1996). Thermoalkalophilic lipase of Bacillus thermocatenulatus. I. Molecular cloning, nucleotide sequence, purification and some properties. Biochim. Biophys. Acta 1301, 105-114. doi: 10.1016/0005-2760(96)00027-6

Shah, N. P. (1994). Psychrotrophs in milk: a review. Milchwissenschaft 49, 432-437. Shamsuzzaman, K., Modler, W., and McKellar, R. C. (1986). Survival of lipase during manufacture of nonfat dry milk. J. Dairy Sci. 70, 746-751. doi: 10.3168/ jds.S0022-0302(87)80069-3

Siddiqui, I. A., Haas, D., and Heeb, S. (2005). Extracellular protease of Pseudomonas fluorescens CHA0, a biocontrol factor with activity against the root-knot nematode Meloidogyne incognita. Appl. Environ. Microbiol. 71, 5646-5649. doi: 10.1128/AEM.71.9.5646-5649.2005

Snellman, E. A., Sullivan, E. R., and Colwell, R. R. (2002). Purification and properties of the extracellular lipase, LipA, of Acinetobacter sp. RAG-1. Eur. J. Biochem. 269, 5771-5779. doi: 10.1046/j.1432-1033.2002.03235.x

Son, M., Moon, Y., Oh, M. J., Han, S. B., Park, K. H., Kim, J.-G., et al. (2012). Lipase and peptidase double-deletion mutant of Pseudomonas fluorescens suitable for extracellular protein production. Appl. Environ. Microbiol. 78, 8454-8462. doi: 10.1128/aem.02476-12

Sørhaug, T., and Stepaniak, L. (1997). Psychrotrophs and their enzymes in milk and dairy products: quality aspects. Trends Food Sci. Technol. 8, 35-41. doi: 10.1016/S0924-2244(97)01006-6

Stead, D. (1986). Lipases: their characteristics, role in food spoilage and industrial uses. J. Dairy Res. 53, 481-505. doi: 10.1017/S0022029900025103

Stoeckel, M., Lidolt, M., Achberger, V., Glück, C., Krewinkel, M., Stressler, T., et al. (2016a). Growth of Pseudomonas weihenstephanensis, Pseudomonas proteolytica and Pseudomonas sp. in raw milk: Impact of residual heat-stable enzyme activity on stability of UHT milk during shelf-life. Int. Dairy J. 59, 20-28. doi: 10.1016/ j.idairyj.2016.02.045

Stoeckel, M., Lidolt, M., Stressler, T., Fischer, L., Wenning, M., and Hinrichs, J. (2016b). Heat stability of indigenous milk plasmin and proteases from Pseudomonas: a challenge in the production of ultra-high temperature milk products. Int. Dairy J. 61, 250-261. doi: 10.1016/j.idairyj.2016.06.009

St-Pierre, B., and Wright, A.-D. G. (2013). Metagenomic analysis of methanogen populations in three full-scale mesophilic anaerobic manure digesters operated on dairy farms in Vermont, USA. Bioresour. Technol. 138, 277-284. doi: 10. 1016/j.biortech.2013.03.188

St-Pierre, B., and Wright, A.-D. G. (2014). Comparative metagenomic analysis of bacterial populations in three full-scale mesophilic anaerobic manure digesters. Appl. Microbiol. Biotechnol. 98, 2709-2717. doi: 10.1007/s00253-013-5220-3

Stuknytë, M., Decimo, M., Colzani, M., Silvetti, T., Brasca, M., Cattaneo, S., et al. (2016). Extracellular thermostable proteolytic activity of the milk spoilage bacterium Pseudomonas fluorescens PS19 on bovine caseins. J. Dairy Sci. 99, 4188-4195. doi: 10.3168/jds.2016-10894

Takahashi, K. (2013). "Epralysin," in Handbook of Proteolytic Enzymes, 3rd Edn, eds N. D. Rawlings and G. S. Salvesen (London: Elsevier Academic Press), 875-877. doi: 10.1016/B978-0-12-382219-2.00183-6

Tao, K., Yu, X., Liu, Y., Shi, G., Liu, S., and Hou, T. (2007). Cloning, expression, and purification of insecticidal protein Pr596 from locust pathogen Serratia marcescens HR-3. Curr. Microbiol. 55, 228-233. doi: 10.1007/s00284-0070096-Z

Tavano, O. L. (2013). Protein hydrolysis using peptidases: an important tool for food biotechnology. J. Mol. Catal. B Enzym. 90, 1-11. doi: 10.1016/j.molcatb. 2013.01.011

Teh, K. H., Flint, S., Palmer, J., Andrewes, P., Bremer, P., and Lindsay, D. (2012). Proteolysis produced within biofilms of bacterial isolates from raw milk tankers. Int. J. Food Microbiol. 157, 28-34. doi: 10.1016/j.ijfoodmicro.2012.04.008

Teh, K. H., Flint, S., Palmer, J., Andrewes, P., Bremer, P., and Lindsay, D. (2014a). Biofilm - An unrecognised source of spoilage enzymes in dairy products? Int. Dairy J. 34, 32-40. doi: 10.1016/j.idairyj.2013.07.002

Teh, K. H., Flint, S., Palmer, J., Lindsay, D., Andrewes, P., and Bremer, P. (2011). Thermo-resistant enzyme-producing bacteria isolated from the internal surfaces of raw milk tankers. Int. Dairy J. 21, 742-747. doi: 10.1016/j.idairyj. 2011.04 .013

Teh, K. H., Lindsay, D., Palmer, J., Andrewes, P., Bremer, P., and Flint, S. (2014b). Proteolysis in ultra-heat-treated skim milk after exposure to multispecies biofilms under conditions modelling a milk tanker. Int. J. Dairy Technol. 67, 176-181. doi: 10.1111/1471-0307.12114

Ternström, A., Lindberg, A. M., and Molin, G. (1993). Classification of the spoilage flora of raw and pasteurized bovine milk, with special reference to 
Pseudomonas and Bacillus. J. Appl. Bacteriol. 75, 25-34. doi: 10.1111/j.13652672.1993.tb03403.x

Todhunter, D., Smith, K., and Hogan, J. (1995). Environmental streptococcal intramammary infections of the bovine mammary gland. J. Dairy Sci. 78, 2366-2374. doi: 10.3168/jds.S0022-0302(95)76864-3

Tondo, E., Lakus, F., Oliveira, F., and Brandelli, A. (2004). Identification of heat stable peptidase of Klebsiella oxytoca isolated from raw milk. Lett. Appl. Microbiol. 38, 146-150. doi: 10.1111/j.1472-765X.2003.01461.x

Vacheyrou, M., Normand, A.-C., Guyot, P., Cassagne, C., Piarroux, R., and Bouton, Y. (2011). Cultivable microbial communities in raw cow milk and potential transfers from stables of sixteen French farms. Int. J. Food Microbiol. 146, 253-262. doi: 10.1016/j.ijfoodmicro.2011.02.033

Valero, E., Villamiel, M., Miralles, B., Sanz, J., and Martı ìnez-Castro, I. (2001). Changes in flavour and volatile components during storage of whole and skimmed UHT milk. Food Chem. 72, 51-58. doi: 10.1016/S0308-8146(00) 00203-X

van den Broeck, D., Bloemberg, V. G., and Lugtenberg, B. (2005). The role of phenotypic variation in rhizosphere Pseudomonas bacteria. Environ. Microbiol. 7, 1686-1697. doi: 10.1111/j.1462-2920.2005.00912.x

Vanetti, M. C. D. (2009). "Spoilage detection," in Handbook of Dairy Foods Analysis, eds L. M. L. Nollet and F. Toldrá (Boca Raton, FL: CRC Press), 665-676.

Verdier-Metz, I., Gagne, G., Bornes, S., Monsallier, F., Veisseire, P., DelbèsPaus, C., et al. (2012). Cow teat skin, a potential source of diverse microbial populations for cheese production. Appl. Environ. Microbiol. 78, 326-333. doi: 10.1128/AEM.06229-11

Vianna, P. C., Walter, E. H., Dias, M. E., Faria, J. A., Netto, F. M., and Gigante, M. L. (2012). Effect of addition of $\mathrm{CO} 2$ to raw milk on quality of UHT-treated milk. J. Dairy Sci. 95, 4256-4262. doi: 10.3168/jds.2012-5387

Vilar, M., Rodriguez-Otero, J., Dieguez, F., Sanjuan, M., and Yus, E. (2008). Application of ATP bioluminescence for evaluation of surface cleanliness of milking equipment. Int. J. Food Microbiol. 125, 357-361. doi: 10.1016/j. ijfoodmicro.2008.04.024

Vilar, M. J., Rodriguez-Otero, J. L., Sanjuan, M. L., Diéguez, F. J., Varela, M., and Yus, E. (2012). Implementation of HACCP to control the influence of milking equipment and cooling tank on the milk quality. Trends Food Sci. Technol. 23, 4-12. doi: 10.1016/j.tifs.2011.08.002

Vithanage, N. R., Dissanayake, M., Bolge, G., Palombo, E. A., Yeager, T. R., and Datta, N. (2016). Biodiversity of culturable psychrotrophic microbiota in raw milk attributable to refrigeration conditions, seasonality and their spoilage potential. Int. Dairy J. 57, 80-90. doi: 10.1016/j.idairyj.2016.02.042
Vithanage, N. R., Yeager, T. R., Jadhav, S. R., Palombo, E. A., and Datta, N. (2014). Comparison of identification systems for psychrotrophic bacteria isolated from raw bovine milk. Int. J. Food Microbiol. 189, 26-38. doi: 10.1016/j.ijfoodmicro. 2014.07.023

von Neubeck, M., Baur, C., Krewinkel, M., Stoeckel, M., Kranz, B., Stressler, T., et al. (2015). Biodiversity of refrigerated raw milk microbiota and their enzymatic spoilage potential. Int. J. Food Microbiol. 211, 57-65. doi: 10.1016/j.ijfoodmicro. 2015.07.001

von Neubeck, M., Huptas, C., Glück, C., Krewinkel, M., Stoeckel, M., Stressler, T., et al. (2016). Pseudomonas helleri sp. nov. and Pseudomonas weihenstephanensis sp. nov., isolated from raw cow's milk. Int. J. Syst. Evol. Microbiol. 66, 1163-1173. doi: 10.1099/ijsem.0.000852

Woods, R. G., Burger, M., Beven, C.-A., and Beacham, I. R. (2001). The aprX-lipA operon of Pseudomonas fluorescens B52: a molecular analysis of metallopeptidase and lipase production. Microbiology 147, 345-354. doi: 10. 1099/00221287-147-2-345

Wu, J.-W., and Chen, X.-L. (2011). Extracellular metalloproteases from bacteria. Appl. Microbiol. Biotechnol. 92, 253-262. doi: 10.1007/s00253-011-3532-8

Zadoks, R., Allore, H., Barkema, H., Sampimon, O., Wellenberg, G., Gröhn, Y., et al. (2001). Cow-and quarter-level risk factors for Streptococcus uberis and Staphylococcus aureus mastitis. J. Dairy Sci. 84, 2649-2663. doi: 10.3168/jds. S0022-0302(01)74719-4

Zhang, S., Li, H., Uluko, H., Liu, L., Pang, X., and Lv, J. (2015). Investigation of peptidase production by Pseudomonas fluorescens BJ-10 and degradation on milk proteins. J. Food Process. Pres. 39, 2466-2472. doi: 10.1111/jfpp.12496

Zhang, S., Liu, L., Pang, X., Lu, J., Kong, F., and Lv, J. (2016). Use of microfiltration to improve quality and shelf life of ultra-high temperature milk. J. Food Process. Pres. 40, 707-714. doi: 10.1111/jfpp.12651

Conflict of Interest Statement: The authors declare that the research was conducted in the absence of any commercial or financial relationships that could be construed as a potential conflict of interest.

Copyright ๑ 2017 Machado, Baglinière, Marchand, Van Coillie, Vanetti, De Block and Heyndrickx. This is an open-access article distributed under the terms of the Creative Commons Attribution License (CC BY). The use, distribution or reproduction in other forums is permitted, provided the original author(s) or licensor are credited and that the original publication in this journal is cited, in accordance with accepted academic practice. No use, distribution or reproduction is permitted which does not comply with these terms. 